\title{
EVALUATION OF LOW TEMPERATURE ALUMINUM DISSOLUTION IN TANK 51
}

\author{
J. A. Pike
}

September 2008

Savannah River National Laboratory

Savannah River Nuclear Solutions

Savannah River Site

Aiken, SC 29808

Prepared for the U.S. Department of Energy Under

Contract Number DE-AC09-08SR22470

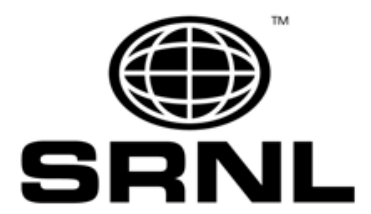




\section{DISCLAIMER}

This work was prepared under an agreement with and funded by the U.S. Government.

Neither the U. S. Government or its employees, nor any of its contractors, subcontractors or their employees, makes any express or implied:

1. warranty or assumes any legal liability for the accuracy, completeness, or for the use or results of such use of any information, product, or process disclosed; or

2. representation that such use or results of such use would not infringe privately owned rights; or

3. endorsement or recommendation of any specifically identified commercial product, process, or service.

Any views and opinions of authors expressed in this work do not necessarily state or reflect those of the United States Government, or its contractors, or subcontractors.

Printed in the United States of America

Prepared For

U.S. Department of Energy 
SRNS-STI-2008-00021

REVISION 0

KEYWORDS: HLW Sludge,

Aluminum Dissolution

RETENTION: PERMANENT

\title{
EVALUATION OF LOW TEMPERATURE ALUMINUM DISSOLUTION IN TANK 51
}

\author{
J. A. Pike
}

September 2008

Savannah River National Laboratory

Savannah River Nuclear Solutions

Savannah River Site

Aiken, SC 29808

Prepared for the U.S. Department of Energy Under

Contract Number DE-AC09-08SR22470

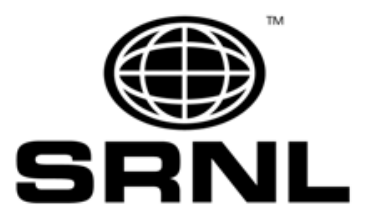




\section{REVIEWS AND APPROVALS}

\section{AUTHOR(S):}

J. A. Pike, Engineering Modeling and Simulation

Date

\section{TECHNICAL REVIEWERS:}

J. M. Gillam, LW Sludge and Salt Planning

Date

F. G. Smith, III, Engineering Modeling and Simulation

Date

\section{APPROVERS:}

H. B. Shah, Lead, LW Sludge and Salt Planning

Date

A. W. Wiggins, Manager, Tank Farm Process Engineering

Date

J. Stuberfield, Jr., Project Owner, Technology Development and Tank Closure Date

S. J. Hensel, Manager, Engineering Modeling and Simulation

Date 


\section{SUMMARY}

Liquid Waste Organization (LWO) identified aluminum dissolution as a method to mitigate the effect of having about 50\% more solids in High Level Waste (HLW) sludge than previously planned. Previous aluminum dissolution performed in a HLW tank in 1982 was performed at approximately $85^{\circ} \mathrm{C}$ for 5 days, which became the baseline aluminum dissolution process. LWO initiated a project to modify a waste tank to meet these requirements.

Subsequent to an alternative evaluation, LWO management identified an opportunity to perform aluminum dissolution on sludge destined for Sludge Batch 5, but within a limited window that would not allow time for any modifications for tank heating. A variation of the baseline process, dubbed Low Temperature Aluminum Dissolution (LTAD), was developed based on the constraint of available energy input in Tank 51 and the window of opportunity, but was not constrained to a minimum extent of dissolution, i.e. dissolve as much aluminum as possible within the time available. This process was intended to operate between 55 and $70^{\circ} \mathrm{C}$, but for a significantly longer time than the baseline process. LTAD proceeded in parallel with the baseline project.

The preliminary evaluation at the completion of LTAD focused on the material balance and extent of the aluminum dissolved. The range of values of extent of dissolution, $56 \%$ to $64 \%$, resulted from the variation in liquid phase sample data available at the time. Additional solid phase data is available from a sample taken after LTAD to refine this range. This report provides additional detailed evaluation of the LTAD process based on analytical and field data and includes:

- a summary of the process chronology,

- a determination of an acceptable blending strategy for the aluminum-laden supernate stored in Tank 11,

- an update to the determination of aluminum dissolved using more complete sample results,

- a determination of the effect of LTAD on uranium, plutonium, and other metals,

- a determination of the rate of heat loss from a quiescent tank, and

- an evaluation of the aluminum dissolution rate model and actual dissolution rate.

LTAD was successfully completed in Tank 51 with minimal waste tank changes. The following general conclusions may be drawn about the LTAD process:

- Dissolution at about $60^{\circ} \mathrm{C}$ for 46 days dissolved $64 \%$ of the aluminum from the sludge slurry.

- The aluminum-laden leach solution decanted to Tank 11 can be blended with a wide variety of supernates without risk of precipitating the dissolved aluminum based on thermodynamic chemical equilibrium models.

- Uranium and plutonium leached into solution without corresponding leaching of iron or metal other than aluminum, but the total mass leached was a small fraction of the total uranium and plutonium in the sludge.

- The concentration of uranium and plutonium in the leach solution was indistinguishable from other tank farm supernates, thus, the leach solutions can be managed relative to the risk of criticality like any other supernate.

- A small amount of mercury leached into solution from the sludge causing the liquid phase concentration to increase 6 to 10 fold, which is consistent with the 4 to 14 fold increase observed during the 1982 aluminum dissolution demonstration.

- Chromium did not dissolve during LTAD. 
- Chloride concentration increased in the liquid phase during LTAD due to chloride contamination in the $50 \%$ sodium hydroxide solution.

- The rate of heat loss from Tank 51 at temperatures above $45^{\circ} \mathrm{C}$ appeared linear and predictable at $8 \mathrm{E}+7 \mathrm{cal} / \mathrm{hr}$.

- The rate of heat transfer from Tank 51 did not follow a simplified bulk heat transfer model.

- Prediction of the aluminum dissolution rate was prone to error due to a lack of active specific surface area data of sludge particles.

- The higher than expected dissolution rate during LTAD was likely due to smaller than expected particle sizes of most of the sludge particles.

While evaluating the LTAD process, the dissolved salt solution from Tank 41 that was stored and sampled in Tank 49 was determined to be supersaturated relative to aluminum. Supersaturation in Tank 49 is not a risk to LTAD. However, storing and processing of this supernate carries a risk of solids precipitation, primarily in the form of gibbsite or boehmite. Blending with the supernate in Tank 11 neither increases nor decreases this risk.

LTAD was initiated as an opportunity to substantially mitigate the planned increase in canister production and DWPF lifecycle after the realization of more sludge solids stored in the HLW tanks. As determined from the preliminary evaluation of LTAD, the direct benefit of the decanted liquid stored in Tank 11 represents 45 canisters at 34\% waste loading ${ }^{7}$ with potential indirect benefits for much larger reductions. Application of an aluminum dissolution process to the remaining high aluminum content sludge will potentially reduce the planned canister production by several hundred canisters at $34 \%-38 \%$ waste loading. The successful completion of LTAD shows that:

- Aluminum dissolution can be accomplished without significant modification to the existing facilities.

- Boehmite, a form of aluminum once considered relatively difficult to dissolve from HLW, dissolved readily by the LTAD process.

- Dissolution can be accomplished given an adequate dissolution period even though dissolution is slow.

\section{Recommendations:}

- Continue application of the aluminum dissolution process on high aluminum content sludge.

- Planning for any specific blend of Tank 11 supernate should be evaluated for the risk of precipitating aluminum.

- Include chloride concentration in process planning and monitoring of future aluminum dissolution processes to avoid the risk of chloride-induced corrosion in stainless steel or undesirable effects on downstream processes.

- Use the existing rate model for planning aluminum dissolution until batch specific data is available to refine the predicted dissolution rate. 


\section{CONTENTS}

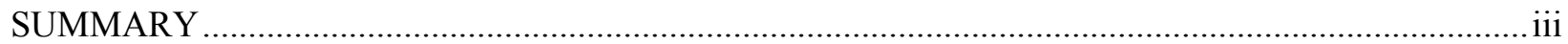

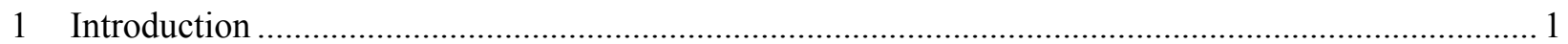

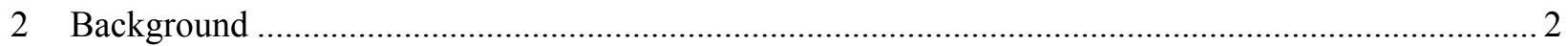

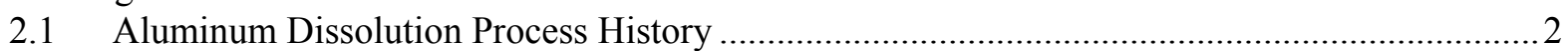

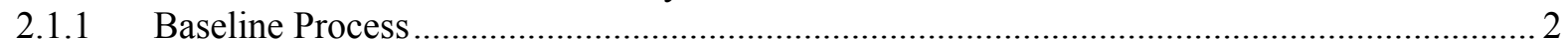

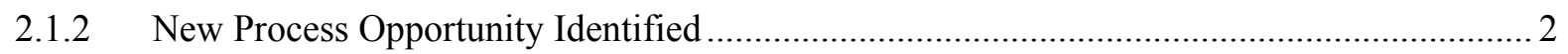

2.2 Dissolution Process Description ...................................................................................... 3

2.3 Chronology

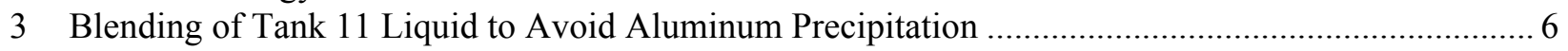

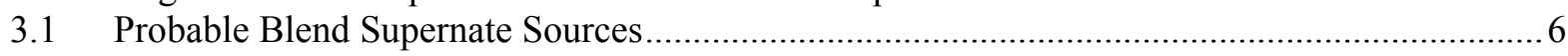

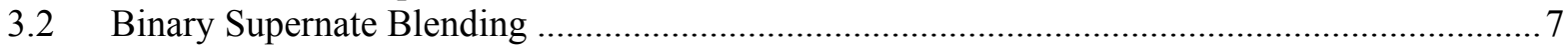

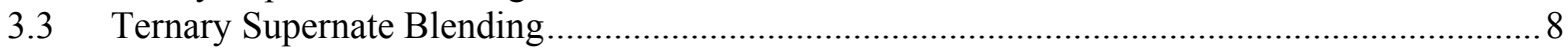

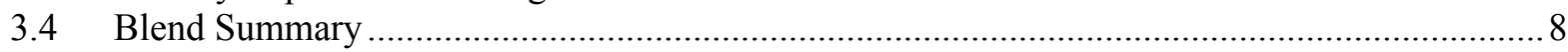

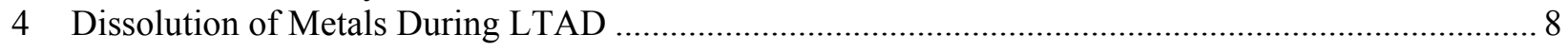

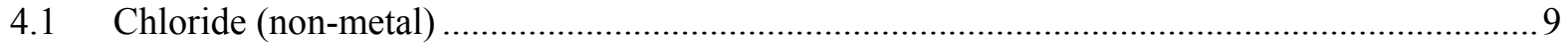

4.2 Updated Results on Extent of Aluminum Dissolved .............................................................. 9

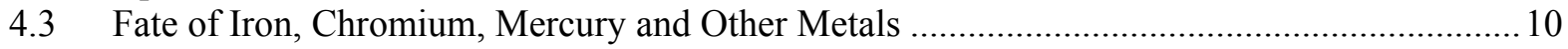

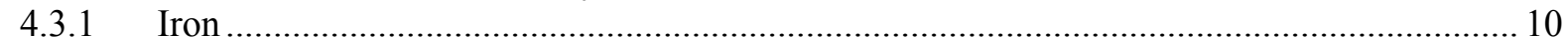

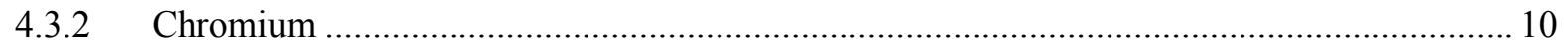

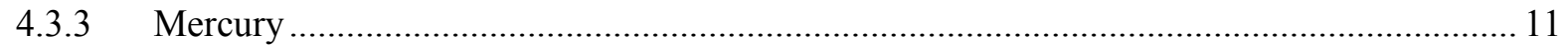

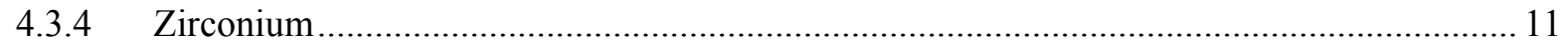

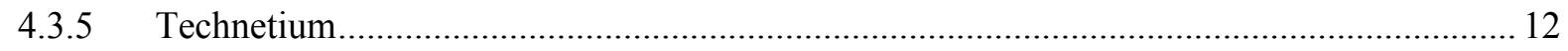

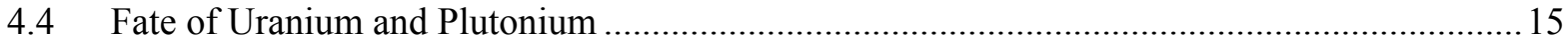

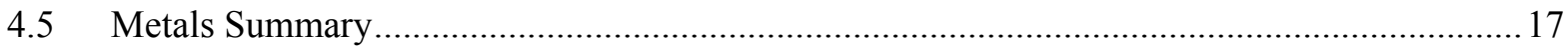

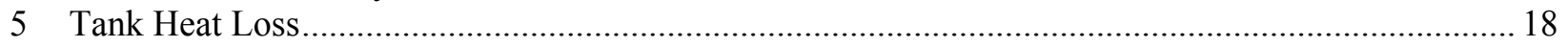

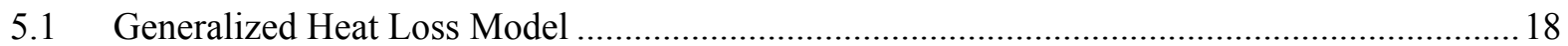

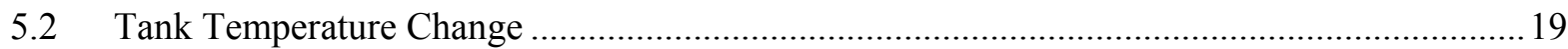

5.3 Estimating Heat Capacity of Sludge and Supernate Layers ..................................................22

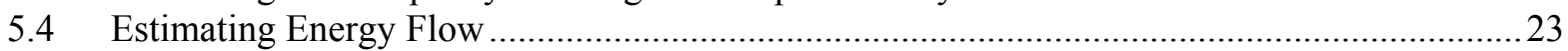

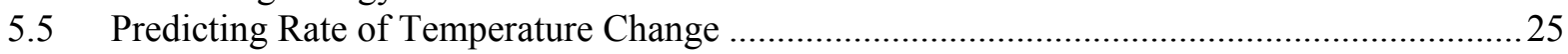

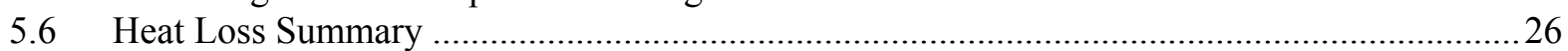

6 Comparison of LTAD Dissolution Rate to Dissolution Rate Model............................................... 26

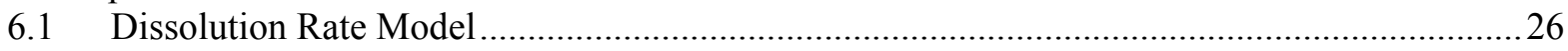

6.2 Model Versus Field Observation................................................................................. 27

6.3 Future Application of the Model ....................................................................................28

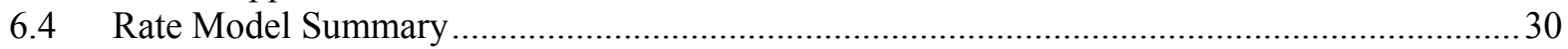

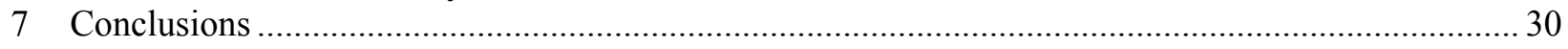

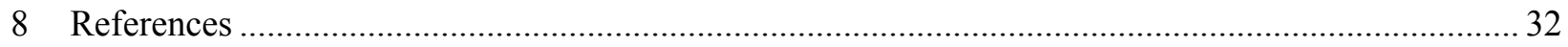




\section{LIST OF TABLES}

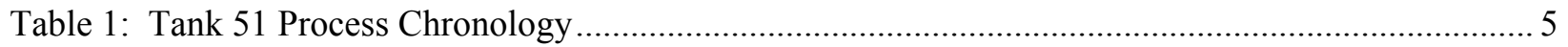

Table 2: Supernate Composition from Tank 11 and Potential Blending Supernates................................ 7

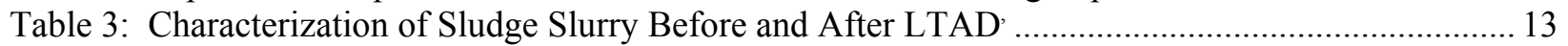

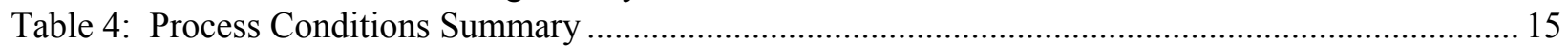

Table 5: Proportions of Key Constituents Leached Out of Sludge .......................................................... 16

Table 6: Concentration of Key Constituents in Caustic Leachate and Supernatant Waste Solutions........ 16

Table 7: Concentrations of Fissile Uranium and Plutonium Isotopes in Caustic Leachate Solutions ....... 17

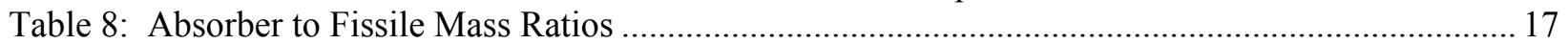

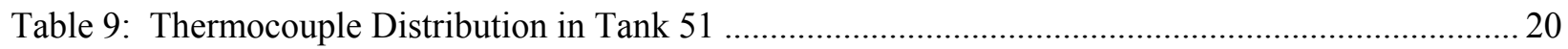

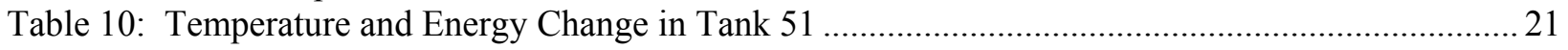

Table 11: Physical Parameters of Tank 51 Sludge Slurry During Quiescent Periods ..............................23

Table 12: Summary of Aluminum Dissolution Rate Equation Constants Estimated from Test Data ....... 27

\section{LIST OF FIGURES}

Figure 1: Aluminum Removal Flow Diagram for Sludge Batch 5 ...................................................... 4

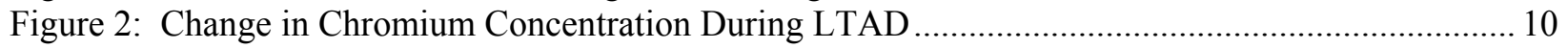

Figure 3: Change in Mercury Concentration During LTAD ................................................................ 11

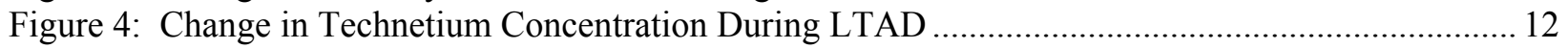

Figure 5: Overall Average Tank Temperature During Quiescent Periods..............................................22

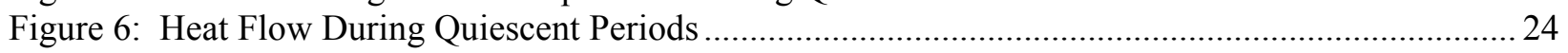

Figure 7: LTAD Dissolution Rate Data Versus the Dissolution Rate Model .......................................... 28

Figure 8: Lab Demonstration of LTAD Dissolution Rate Data Versus the Dissolution Rate Model ......... 30

\section{LIST OF ACRONYMS}

LWO Liquid Waste Organization

LTAD Low Temperature Aluminum Dissolution

DWPF Defense Waste Processing Facility

SPF Saltstone Processing Facility

SWPF Salt Waste Processing Facility

ARP Actinide Removal Process

MCU Modular Caustic-side Solvent Extraction Unit

HLW High Level Waste 


\section{INTRODUCTION}

Liquid Waste Organization (LWO) completed the Low Temperature Aluminum Dissolution (LTAD) process. The LTAD process was designed to dissolve aluminum solids from the sludge slurry in Tank 51 by application of sodium hydroxide and heat. Previous dissolution performed in a High Level Waste (HLW) tank was completed at approximately $85^{\circ} \mathrm{C}$ for 5 days, whereas, this process was intended to operate between 55 and $70^{\circ} \mathrm{C}$, but for a significantly longer time. A preliminary evaluation of LTAD determined the following: ${ }^{7}$

- Analytical results of the liquid phase show $26,800-30,400 \mathrm{~kg}$ of aluminum, $56-64 \%$ of the aluminum originally in Tank 51 sludge slurry, dissolved.

- The aluminum that dissolved from the sludge slurry reduced the sludge solids mass from 188,000 $\mathrm{kg}$ to about $100,000-110,000 \mathrm{~kg}$ for a total solids reduction of $78,000 \mathrm{~kg}-88,000 \mathrm{~kg}$ of sludge solids as $\mathrm{Al}(\mathrm{OH})_{3}$.

- The total amount of aluminum dissolved exceeded the original planned estimate of $50 \%$, but was within the range of variability from the planned amount $(24-84 \%)$.

- $35,700-34,100 \mathrm{~kg}$ of aluminum remains in Tank 51 after the transfer to Tank 11 , where $42 \%-$ $50 \%$ of the remaining aluminum is in the liquid phase.

- Tank 11 currently stores $12,900-14,500 \mathrm{~kg}$ of dissolved aluminum, which is equivalent to $37,300-41,900 \mathrm{~kg}$ of the original sludge mass in Tank 51 as $\mathrm{Al}(\mathrm{OH})_{3}$.

- An estimated $13,100-15,200 \mathrm{~kg}$ of aluminum, equivalent to $37,800-43,900 \mathrm{~kg}$ of sludge mass, will be washed out of the sludge during sludge washing based on equivalent sodium to total sludge mass target of the original flowsheet.

- The total potential reduction in canister production at the Defense Waste Processing Facility (DWPF) is estimated from $116-126$ canisters at $38 \%$ waste loading with $40-45$ of the total represented by the liquid stored in Tank 11 .

The preliminary evaluation of LTAD focused on the material balance and extent of the aluminum dissolved. The range of values resulted from the variation in liquid phase sample data available at the time. Additional solid phase data from a sample taken after LTAD is available to refine the range. This report provides additional detailed evaluation of the LTAD process based on analytical and field data.

This document includes:

- a summary of the process chronology,

- a determination of an acceptable blending strategy for the aluminum-laden supernate stored in Tank 11,

- an update to the determination of aluminum dissolved using more complete sample results,

- a determination of the effect of LTAD on uranium, plutonium, and other metals,

- a determination of the rate of heat loss from a quiescent tank, and

- an evaluation of the aluminum dissolution rate model and actual dissolution rate. 


\section{BACKGROUND}

\subsection{Aluminum Dissolution Process History}

An evaluation of sludge mass remaining in the HLW Tank Farms shows about 50\% more solids in the sludge than previously estimated. ${ }^{1}$ The new estimate will affect the estimated life cycle cost and schedule for HLW disposition. Consequently, Washington Savannah River Company chartered a LWO Technology Development team to evaluate techniques to mitigate these life cycle impacts. The Technology Development Team focused on three areas: reducing the sludge mass, new melter technology, and DWPF flowsheet improvements. One promising mitigation option was aluminum dissolution, which offers the potential for significantly reducing the quantity of sludge solids sent to the DWPF, thus, reducing the number of canisters produced.

The Team established a two-part strategy: 1) develop a known baseline solids mass reduction process by dissolution of aluminum from the solids, and 2) perform an alternative technology identification and evaluation to replace the baseline process if a better technology is found.

\subsubsection{Baseline Process}

Aluminum is dissolved from sludge waste into the supernate by treatment with caustic at moderate to high temperatures, where decantation and water washing subsequently remove the aluminum. Aluminum solids in the sludge are believed to be present primarily in three compounds - aluminum trihydrate or gibbsite, alumina monohydrate or boehmite, and aluminosilicate. With caustic treatment, the gibbsite form dissolves readily at the relatively low dissolving temperatures possible in the waste tanks. The boehmite form dissolves much more slowly and is somewhat less soluble than gibbsite. The aluminosilicate has such low solubility in waste slurries that it is generally considered insoluble.

Aluminum dissolution was performed in a full-scale demonstration in 1982 by adding $50 \mathrm{wt} \% \mathrm{NaOH}$ to the process tank, Tank 42 . Steam heating was used to hold the slurry temperature at $85^{\circ} \mathrm{C}$ for three to five days while continuously mixing the sludge. The caustic was added in sufficient quantity to provide a minimum initial ratio of 3 moles of free hydroxide per mole of acid soluble aluminum (gibbsite) and to provide a final liquid phase free hydroxide molarity of 3 . The actual conditions during dissolution varied from these initial conditions due to a variety of operational issues, but roughly approximated these conditions.

During the full-scale demonstration in 1982, a total of 104,000 gallons of $50 \mathrm{wt} \%$ sodium hydroxide and 118,000 gallons of dissolved salt solution were added to 125,000 gallons of high aluminum sludge. Initial dissolving conditions were $1.3 \mathrm{M} \mathrm{NO}_{3}^{-}, 0.28 \mathrm{M} \mathrm{NO}_{2}^{-}$, and $3.64 \mathrm{M} \mathrm{OH}^{-}$. The tank was heated from 63 to $83^{\circ} \mathrm{C}$ in 38 hours with steam spargers $(6000 \mathrm{lb} / \mathrm{hr})$ and was continuously agitated. Thereafter, a steam flow of $1000 \mathrm{lb} / \mathrm{hr}$ was used to maintain tank temperatures between 83 and $85^{\circ} \mathrm{C}$. After five days of digestion, sample analyses indicated that approximately $80 \%$ of the total aluminum in the sludge had dissolved. $^{2}$

\subsubsection{New Process Opportunity Identified}

Subsequent to the alternative evaluation, LWO management identified an opportunity to perform aluminum dissolution on sludge destined for Sludge Batch 5, but within a limited window that would not allow time for any modifications for tank heating. A variation of the baseline process, dubbed LTAD, 
SRNS-STI-2008-00021

REVISION 0

was developed based on the constraint of available energy input in Tank 51 and the window of opportunity, but was not constrained to a minimum extent of dissolution. LTAD proceeded in parallel with the baseline project.

The window of opportunity developed when a portion of the sludge slurry prepared in Tank 51 for Sludge Batch 4 remained in Tank 51 for development of Sludge Batch 5. Sludge Batch 4 was prepared by transferring part of the sludge slurry from Tank 51 to Tank 40, leaving roughly $2 / 3$ of the slurry to be combined with additional sludge from F-Area for Sludge Batch 5. The slurry in Tank 51 contained sludge slurry from Tank 11, which contained a significant concentration of aluminum. A window of opportunity resulted from lag between the time slurry was transferred to Tank 40 and when the slurry from F-Area was ready to transfer.

\subsection{Dissolution Process Description}

The dissolution process consisted of the following steps:

1. Cooling water to Tank 51 was valved out.

2. Forty-three 3000 -gallon tankers of $50 \%$ sodium hydroxide solution were unloaded to Tank 51 via HPT 7 and HPT 8.

3. Two to four slurry pumps were used to mix Tank 51 periodically during the batch transfers of caustic from HPT 7 and HPT 8 to Tank 51.

4. Two to four slurry pumps were used to increase slurry temperature in Tank 51 and maintain the temperature as warm as practical. The temperature ranged from about 55 to $64^{\circ} \mathrm{C}$ during the entire treatment time.

5. Tank 51 was mixed for the number of days available, which resulted in 46 day dissolution period, including a 12-day mixing break due to slurry pump and ventilation system maintenance.

6. Slurry pumps were turned off and the sludge slurry was allowed to settle for 29 days.

7. About 307,000 gallons of aluminum-laden supernate was decanted to the storage tank, Tank 11 .

8. Sludge Batch 5 preparation proceeded.

9. Aluminum-laden supernate is currently stored for feed to the Salt Waste Processing Facility (SWPF), Actinide Removal Process (ARP)-Modular Caustic-side Solvent Extraction Unit (MCU), or any other salt waste process installed in the future.

Figure 1 shows the process flow diagram in context with downstream processes. The SWPF block could be replaced with ARP-MCU. ${ }^{3}$ 
SRNS-STI-2008-00021

REVISION 0

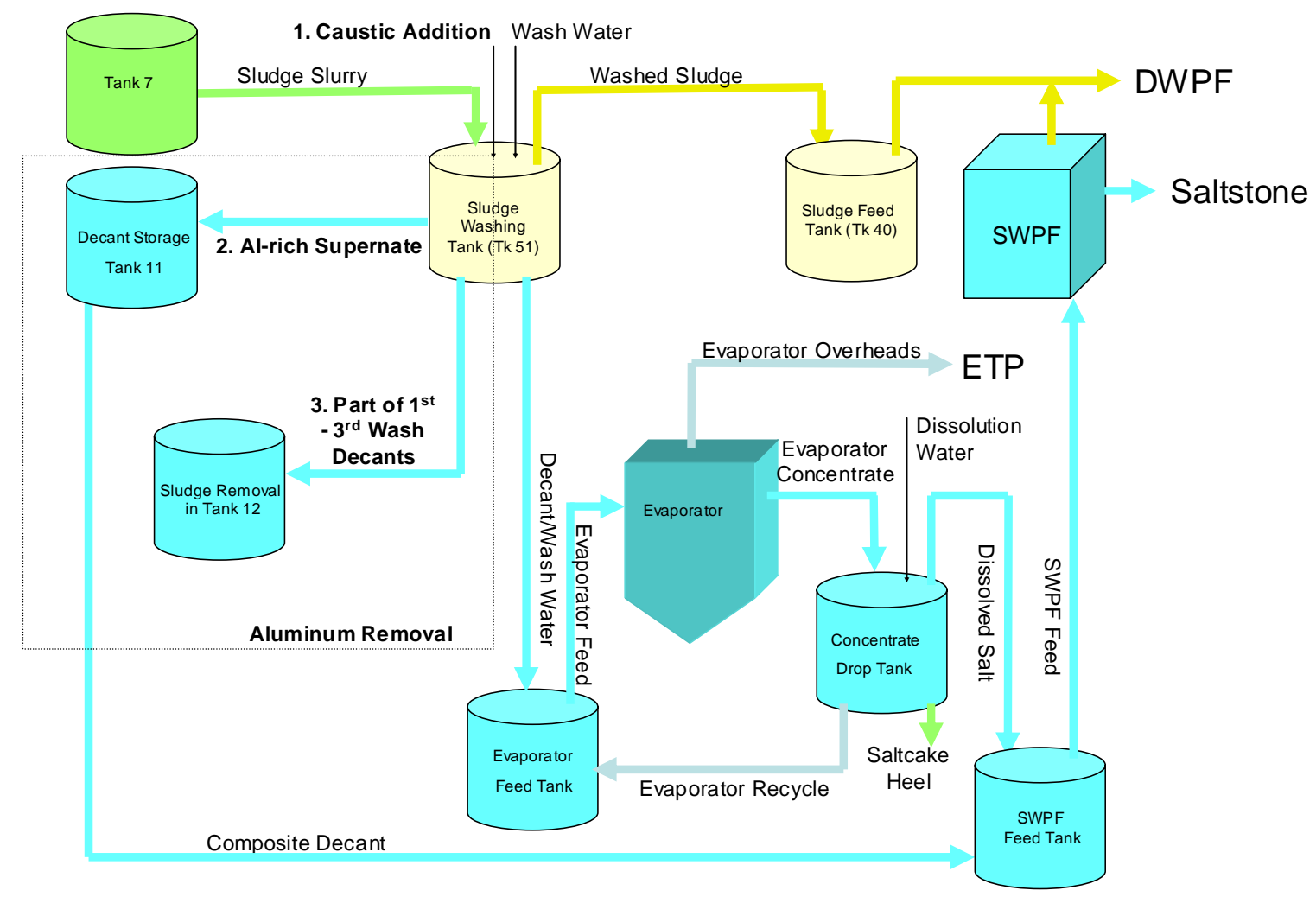

Figure 1: Aluminum Removal Flow Diagram for Sludge Batch 5

\subsection{Chronology}

Table 1 shows the process chronology during the aluminum dissolution process.

The contents of forty-three tanker trucks of $50 \mathrm{wt} \%$ sodium hydroxide were added to Tank 51 by unloading the tankers into pump tanks HPT-7 and HPT-8 and transferring the solution to Tank 51.

The extent of aluminum dissolved was higher than the nominal fraction planned, 50\%, thus, necessitating a sodium hydroxide supplemental addition to Tank 11 in order to avoid reprecipitation of aluminum during storage in Tank 11. 
SRNS-STI-2008-00021

REVISION 0

Table 1: Tank 51 Process Chronology

\begin{tabular}{|c|c|c|c|}
\hline Date & Event & $\begin{array}{l}\text { Tank } 51 \text { Level* } \\
\quad \text { (inches) }\end{array}$ & $\begin{array}{l}\text { Tank } 11 \text { Level* } \\
\text { (inches) }\end{array}$ \\
\hline $10 / 30 / 07$ & First caustic tanker truck unloaded. & 140.8 & \\
\hline 11/7/07 & Initial Tank 11 level & & 6.8 \\
\hline 11/10/07 & Inhibited water added to Tank 11 for pump test & & 17.0 \\
\hline 11/08/07 & First dip sample after 15 tankers unloaded. & 153.0 & \\
\hline 11/14/07 & Slurry pumps started running to heat tank. & & \\
\hline 11/15/07 & Second dip sample after 33 tankers unloaded. & 169.7 & \\
\hline 11/19/07 & Last caustic tanker unloaded. & 181.6 & \\
\hline 11/20/07 & Third dip sample taken. & 183.2 & \\
\hline 11/23/07 & Fourth dip sample taken. & 183.2 & \\
\hline 11/26/07 & Fifth dip sample taken. & & \\
\hline 11/29/07 & Sixth dip sample taken. & 185.7 & \\
\hline $12 / 2 / 07$ & Seventh dip sample taken. & 185.8 & \\
\hline $12 / 5 / 07$ & Eighth dip sample taken. & 188.5 & \\
\hline $12 / 10 / 07$ & Nineth dip sample taken. & 189.3 & \\
\hline $12 / 10 / 07$ & $\begin{array}{l}\text { Mixing suspended due to pump problems, } \\
\text { settling begins. }\end{array}$ & & \\
\hline $12 / 22 / 07$ & Corrosion program dip sample taken. & 189.0 & \\
\hline $12 / 22 / 07$ & Mixing resumes after sampling. & & \\
\hline 1/4/08 & Planned settling begins, mixing stopped. & 192.9 & \\
\hline 1/21/08 & Tenth dip sample taken. & & \\
\hline $1 / 29-30 / 08$ & 4 tanker trucks of caustic unloaded to Tank 11 & & 22.4 \\
\hline $2 / 2 / 08$ & Supernate transfer to Tank 11 initiated. & 192.5 & \\
\hline \multirow[t]{2}{*}{ 2/11/08 } & Supernate transfer to Tank 11 completed & 105.5 & 135.8 \\
\hline & Tank 51 mixed for 24 hours. & & \\
\hline 2/11/08 & Dip sample taken from Tank 11. & & 135.8 \\
\hline 2/12/08 & 3-L sample taken from Tank 51. & 105.5 & \\
\hline
\end{tabular}

* As measured by the reel tape installed on the tank. 


\section{BLENDING OF TANK 11 LIQUID TO AVOID ALUMINUM PRECIPITATION}

The LTAD was designed to avoid precipitation from the aluminum-laden leach solution stored in Tank 11. To avoid precipitation during storage, $50 \mathrm{wt} \%$ sodium hydroxide solution was added to Tank 11 before the leach solution was transferred into the tank. This addition became necessary because the amount of aluminum dissolved exceeded the planning basis. ${ }^{4}$

In the future, the liquid in Tank 11 will be blended with some amount of other waste supernates as part of feed batch for SWPF or other salt waste process. These blends need to avoid precipitating conditions so that the aluminum does not end up in a solid slurry destined for DWPF. If the aluminum remains soluble, then it will follow the liquid phase to the Saltstone Processing Facility (SPF). This evaluation is intended to guide selection of the specific supernate to blend and then a specific evaluation would be needed to determine the correct blend ratio. Potential blends with supernate are evaluated using OLI Stream Analyzer $^{\text {tm }}$ to identify the potential to precipitate solids containing aluminum.

\subsection{Probable Blend Supernate Sources}

Three waste supernates were selected as possible supernates that may be blended with the Tank 11 liquid that represent DWPF recycle, a concentrated salt solution, and a dissolved salt solution. These supernates are identified to represent the probable range of blend materials. Tank 23 represents a dilute supernate, predominantly from DWPF recycle. Tank 30 represents a highly concentrated supernate with high free hydroxide concentration. The supernate in Tank 49 after addition of the third batch of dissolved salt solution from Tank 41 represents dissolved salt solution from the first $1 / 4$ or so of a salt tank. In addition, Tank 49 supernate represents a supernate with high nitrate and nitrite salt content and relatively low free hydroxide concentration.

Other than avoiding precipitation, the only other criterion imposed was to produce a solution at $5.6 \mathrm{M}$ total sodium. $5.6 \mathrm{M}$ total sodium is the target concentration for down stream salt waste processing. 5,6 Other feed criteria will be evaluated with the specific material selected through the waste feed qualification process.

Table 2 shows the composition of Tank 11 as well as the composition of the candidate supernates identified for this blending evaluation. Notice that total sodium concentration in Tank 11 is below $5.6 \mathrm{M}$, so any blend needs to boost the concentration to at least 5.6 M. As such, Tank 23 will not be blended with Tank 11 without some amount of a more concentrated salt solution.

Note that OLI Stream Analyzer ${ }^{\mathrm{tm}}$ reports that the compositions for Tanks 23, 30 and 49 are not at equilibrium. Tank 30 supernate will likely precipitate sulfates, nitrates and nitrites. A small amount of oxalate and carbonate may precipitate, but the precipitating portion of these components is small. Note that aluminum is sub-saturated. Tank 23 supernate is supersaturated in aluminum, indicating more than $90 \%$ of the reported aluminum may precipitate. Tank 49 supernate will likely precipitate fluoride, sulfate, and aluminum. About 0.27 of the $0.57 \mathrm{M}$ of the reported aluminum content or $47 \%$ will tend to precipitate. Tank 11 is sub-saturated in aluminum, so these blends will need to be examined in terms of their propensity to increase and decrease precipitation of aluminum from the blending supernates. 
SRNS-STI-2008-00021

REVISION 0

Table 2: Supernate Composition from Tank 11 and Potential Blending Supernates

\begin{tabular}{|l|c|c|c|c|}
\hline & $\begin{array}{c}\text { Tank 11 } \\
\text { Sample }^{7,11}\end{array}$ & $\begin{array}{c}\text { Tank 23 } \\
\text { (DWPF } \\
\text { Recycle) }\end{array}$ & $\begin{array}{c}\text { Tank 30 } \\
\text { (Concentrated } \\
\text { Supernate) }\end{array}$ & $\begin{array}{c}\text { Tank 49 }^{8} \\
\text { (Filtered Dissolved }^{\text {Saltcake) }}\end{array}$ \\
\hline Sample Date & $2 / 11 / 08$ & $4 / 1 / 08$ & $5 / 29 / 08$ & $6 / 1 / 05$ \\
\hline Specific Gravity & 1.170 & 1.020 & 1.517 & 1.369 \\
\hline Concentration in M: & 4.17 & $0.35^{*}$ & 15.09 & 9.00 \\
\hline $\mathrm{Na}^{+}$ & 0.33 & 0.0721 & 2.11 & 0.350 \\
\hline $\mathrm{NO}_{2}^{-}$ & 0.18 & 0.159 & 1.49 & 4.74 \\
\hline $\mathrm{NO}_{3}^{-}$ & 3.10 & 0.116 & 10.6 & 1.33 \\
\hline $\mathrm{OH}^{-}$ & 0.030 & 0.0053 & & $<0.0039$ \\
\hline $\mathrm{Cl}^{-}$ & 0.017 & 0.0010 & 0.008 & 0.206 \\
\hline $\mathrm{SO}_{4}^{-2}$ & $<0.026$ & & & 0.0074 \\
\hline $\mathrm{F}^{-}$ & 0.098 & & 0.174 & 0.348 \\
\hline $\mathrm{CO}_{3}^{-2}$ & 0.39 & $0.088^{* *}$ & 0.60 & 0.567 \\
\hline $\mathrm{AlO}_{2}^{-}$ & $<0.0057$ & & 0.0056 & 0.0028 \\
\hline $\mathrm{C}_{2} \mathrm{O}_{4}^{-2}$ & $<0.013$ & & 0.0185 & 0.0092 \\
\hline $\mathrm{PO}_{4}^{-{ }^{-2}}$ & 0.0033 & & & \\
\hline $\mathrm{K}^{+}$ & & & \\
\hline
\end{tabular}

* Calculated from anion concentrations.

** Measurement from $2 / 25 / 05$, but should be similar to most recent sample since the waste in the tank is predominantly from the same source.

\# Tanks 23 and 30 sample data are from Liquid Waste Corrosion Sample Database. Tank 30 values are the average of two samples at two different depths.

\subsection{Binary Supernate Blending}

Based on the sodium content shown in Table 2, the ratio of volume of each blending material to Tank 11 is calculated by:

$$
\mathrm{V}_{\mathrm{x}} / \mathrm{V}_{11}=\left([\mathrm{Na}]_{\mathrm{m}}-[\mathrm{Na}]_{11}\right) /\left([\mathrm{Na}]_{\mathrm{x}}-[\mathrm{Na}]_{\mathrm{m}}\right)
$$

where

$$
\begin{aligned}
& \mathrm{x}=\text { the blending tank, } \\
& \mathrm{m}=\text { final blended material, and } \\
& 11=\text { Tank } 11 .
\end{aligned}
$$

The volume ratio of Tank 30:Tank 11 is 0.15 and Tank 49:Tank 11 is 0.42 . At these ratios, the blend with Tank 30 eliminates the propensity to precipitate any salts except for oxalates. Tank 30 likely makes a good blending candidate because of the high hydroxide concentration. The blend with Tank 49 still shows a propensity to precipitate $47 \%$ of the aluminum contributed by Tank 49 in the blend. The propensity to precipitate neither increases nor decreases the blending liquid, which still meets the general goal of not precipitating the aluminum dissolved during LTAD. However, the supersaturated condition of freshly dissolved salt solution will need to be managed by the waste feed qualification program regardless of any blending with Tank 11 . 
Assuming a 10-inch heel after transfer, about 341,000 gallons of the 368,000 gallons of liquid in Tank 11 can be transferred out for a blended feed solution. The minimum blending material needed is 51,400 and 143,000 gallons from Tank 30 and Tank 49 respectively.

\subsection{Ternary Supernate Blending}

A total of 392,000 to 484,000 gallons of feed solution would make a small batch. If the batch size was set at 1,000,000 gallons, then the remaining volume could be made up with a blend of Tank 23 supernate and another supernate while maintaining the same $5.6 \mathrm{M}$ total sodium concentration. In this case, volume blend ratios of Tank 23:Tank 30 and Tank 23:Tank 49 would be 0.55 and 1.54, respectively.

For a Tank 11:Tank 23:Tank 30 blend, the remaining 608,000 gallons of a million gallon batch would have 391,000 gallons of Tank 23 supernate and 216,000 gallons of Tank 30 supernate. Therefore, the ratio for this three-way blend is $341,000: 391,000: 268,000$ gallons or 1:1.15:0.79. This blend is subsaturated with respect to aluminum, but still shows a small propensity to precipitate oxalate. This blend would likely be acceptable.

For a Tank 11:Tank 23:Tank 49 blend, the remaining 516,000 gallons of a million gallon batch would have 203,000 gallons of Tank 23 supernate and 313,000 gallons of Tank 49 supernate. Therefore, the ratio for this three-way blend is $341,000: 203,000: 456,000$ gallons or 1:0.59:1.54. This blend is supersaturated with respect to aluminum exhibiting a propensity to precipitate $70 \%$ of aluminum contributed by Tank 49 supernate, i.e., increasing the propensity to precipitate aluminum. This blend would not be acceptable. Note that the aluminum-laden leach solution stored in Tank 11 is not the cause of the precipitation problem, but the supersaturated liquid in Tank 49 that is diluted by the Tank 23 supernate causes the precipitation. This precipitating condition needs to be addressed separately from any blending with the supernate stored in Tank 11.

\subsection{Blend Summary}

The aluminum-laden liquid stored in Tank 11 can successfully be blended with other supernates to meet the chemical concentration and density needs of salt waste processing without precipitating the dissolved aluminum. The blending supernate needs to have a total sodium concentration well above the nominal 5.6 $\mathrm{M}$ total sodium concentration needed for salt waste processing because the Tank 11 supernate is well below this concentration. Though the most favorable blending supernates are expected to have relatively high hydroxide concentrations, any waste supernate above $6 \mathrm{M}$ total sodium that is sub-saturated relative to aluminum will likely work well. A specific evaluation of the supernates prior to mixing is needed to determine the precise ratios required to meet the total sodium concentration required.

This evaluation identified that existing supernates can be supersaturated relative to aluminum and precipitation can occur, but would be caused by preexisting conditions and not the act of blending. Tank 49 sample results show that the dissolved salt solution can be super saturated and, as such, would not be a good candidate for blending until the liquid reaches equilibrium conditions by precipitating the excess aluminum or the chemistry is adjusted.

\section{DISSOLUTION OF METALS DURING LTAD}

Samples taken during LTAD include a sludge slurry sample with comprehensive characterization of both the liquid and solid phase before and after LTAD in addition to the in-process samples with liquid phase 
characterization only. The results from the samples before and after LTAD were evaluated for changes in the liquid phase composition. Any constituent that indicated a significant change in mass in the liquid phase was compared to the solid phase composition for a corresponding change in mass. The in-process samples were also evaluated for a corresponding trend and any trends in solubility that were not observed in the before and after samples. In addition, equivalent sampling and analysis was performed on the labscale LTAD demonstration.

Trending of the sample results from the 1982 aluminum dissolution process identified increasing solubility in chromium, mercury, and uranium. Silicon solubility was observed to decrease and zinc oxide was expected to dissolve in a reaction with sodium hydroxide to form soluble sodium zincate, but was not observed. ${ }^{9}$ Therefore, similar trends were anticipated during LTAD. The lower process temperature of LTAD at approximately $60^{\circ} \mathrm{C}$ versus $85^{\circ} \mathrm{C}$ during the 1982 demonstration, as well as the much longer dissolution time may have altered observed trends due to both potentially slower rates and more time to reach equilibrium conditions.

Table 3 shows the constituent concentrations of the liquid and solid phase for sludge slurry samples before and after LTAD for both the full-scale process performed in Tank 51 and the laboratory-scale demonstration. The solid phase concentrations were calculated from the slurry by subtracting the liquid phase contribution of each component from the total value measured for the slurry. This method for determining solid phase composition is not very precise when liquid phase contribution to the slurry is large or when the concentration in both phases is close to the detection limit. As such, small changes in solid phase composition are not discernible. Constituents with large mass changes in the liquid or solids phase are highlighted in Table 3.

Other than sodium, aluminum, and hydroxide ion, which are expected to change with LTAD, comparison of the before and after liquid phase shows that the following liquid phase constituents increased: chloride, mercury, uranium, and plutonium.

\subsection{Chloride (non-metal)}

Although chloride is not a metal, chloride was a contaminant in the added caustic solution and is the source of the increase during LTAD. The certificates of analysis for each of the 43 truck loads of $50 \mathrm{wt} \%$ sodium hydroxide solution show about $1 \mathrm{wt} \%$ sodium chloride contamination. The analytical result of the laboratory scale demonstration did not show the increase, but the detection limit for the analysis was higher than the expected concentration. ${ }^{13}$

\subsection{Updated Results on Extent of Aluminum Dissolved}

Preliminary evaluation of LTAD was based on liquid phase analysis only. ${ }^{7,10}$ The preliminary evaluation concluded that $56 \%$ to $64 \%$ of the original aluminum dissolved based on the range in the data available. Solids phase data is available to make a more direct determination and refine the preliminary evaluation. ${ }^{11}$

Table 3 shows that $64 \%$ of the aluminum dissolved from the sludge slurry based on the solids and liquid phase sample data from Tank 51 after LTAD. The solids phase concentration determined from the slurry based analysis confirms the upper range of the preliminary evaluation. The lower value of the range from the preliminary evaluation accounted for the sample results of the decanted liquid from Tank 11. The initial sample results from Tank 11 are likely somewhat low and will be validated with subsequent periodic monitoring samples from Tank 11. 


\subsection{Fate of Iron, Chromium, Mercury and Other Metals}

\subsubsection{Iron}

Iron is identified as a metal of interest for criticality control. The concentrations of dissolved iron from the samples after LTAD and after the lab-scale demonstration were less than the detection level for the sample before LTAD. Examination of the change in mass in the solid phase reveals practically no dissolution of iron. In fact, the results show a small percent increase in mass, which is well within the variability of the sample analysis. Most of the in-process sample results were below detection limits. As such, no trend can be established. Regardless, these results show practically no iron dissolved from the solid phase.

\subsubsection{Chromium}

Generally, the in-process samples show no discernible trend in chromium concentration. Chromium increased in the liquid phase during the 1982 demonstration, but was observed to increase in proportion to level changes from bearing water and other water additions, thus, leading to speculation by the folks originally evaluating the results that the source of chromium may have been from something other than the sludge. ${ }^{9}$ Figure 2 shows the change in chromium concentration during LTAD ${ }^{12}$ and the lab-scale demonstration. ${ }^{13}$ The laboratory scale demonstration suggests an increasing concentration, but LTAD showed no change. In fact, the chromium concentration initially decreased in proportion to the caustic addition due to dilution and then was stable for the entire process, thus, resulting in no change in total chromium in solution as shown in Table 3.

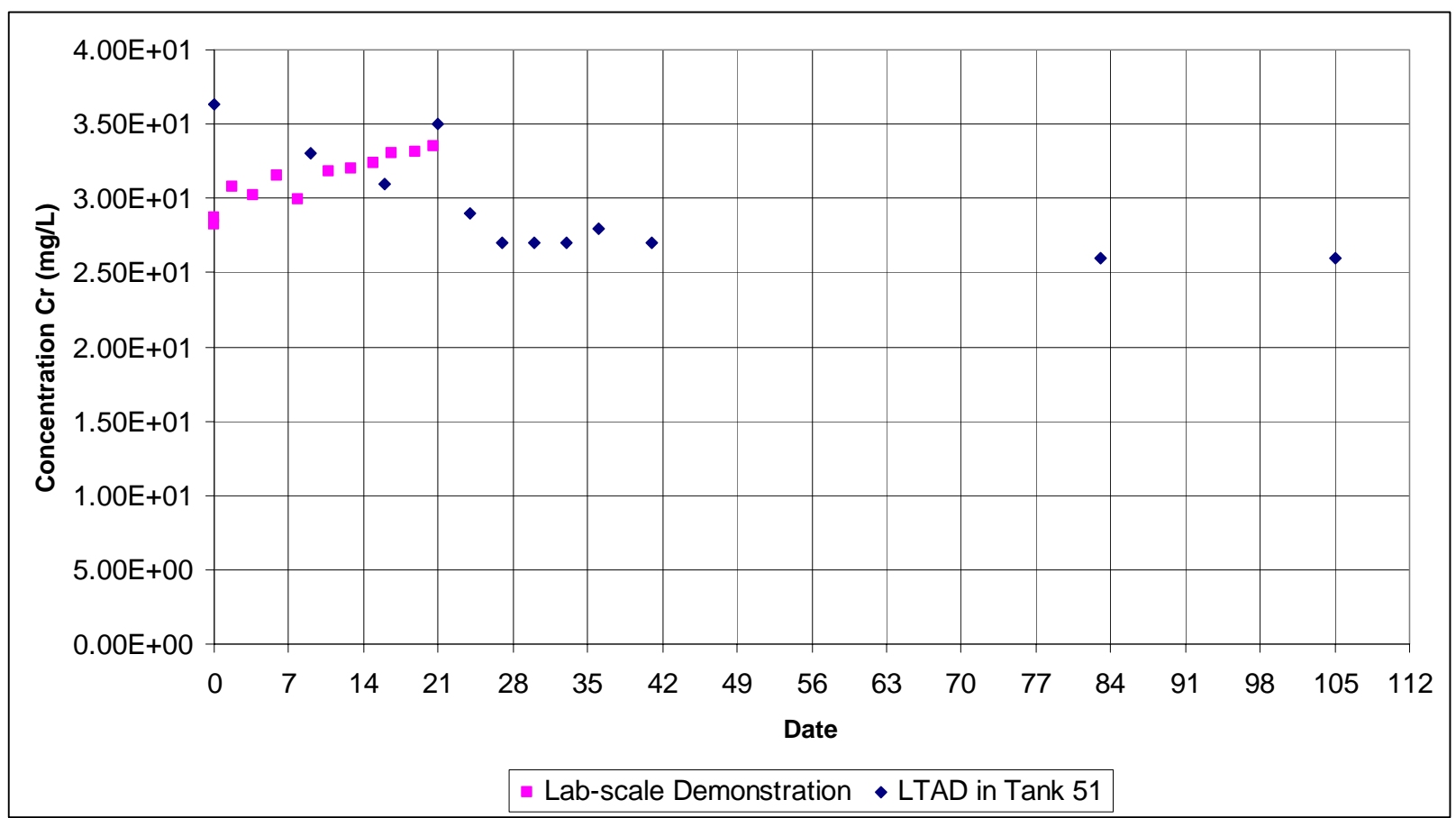

Figure 2: Change in Chromium Concentration During LTAD 


\subsubsection{Mercury}

Mercury concentration increased in the liquid phase as expected, but the solid phase composition shows only a small fraction of the mercury in the sludge dissolved. Figure 3 shows the relative change in mercury concentration from all LTAD samples. ${ }^{11,12}$ Mercury was not periodically measured in the labscale demonstration. The in-process sample analysis was provided by a different method than the before and after samples, so the values at the two ends may not be consistent with all the other values.

Regardless, the in-process samples appear to show an increasing trend over all. Other than the results from the 1/21/08 sample, the in-process sample results tend to cluster near the results of the final sample, which is roughly 5 times higher than the initial concentration. Since the in-process samples start after at least $1 / 3$ of the caustic addition is complete, these results suggest that most of the mercury may have come into solution during caustic addition and was not significantly affected by the duration or temperature.

Mercury content of the liquid phase during the 1982 aluminum dissolution demonstration increased 4 to 14 fold over the initial concentration. The sludge solids data from the 1982 demonstration contains high variability between samples such that any reduction in mercury in the solids is indiscernible. ${ }^{9}$

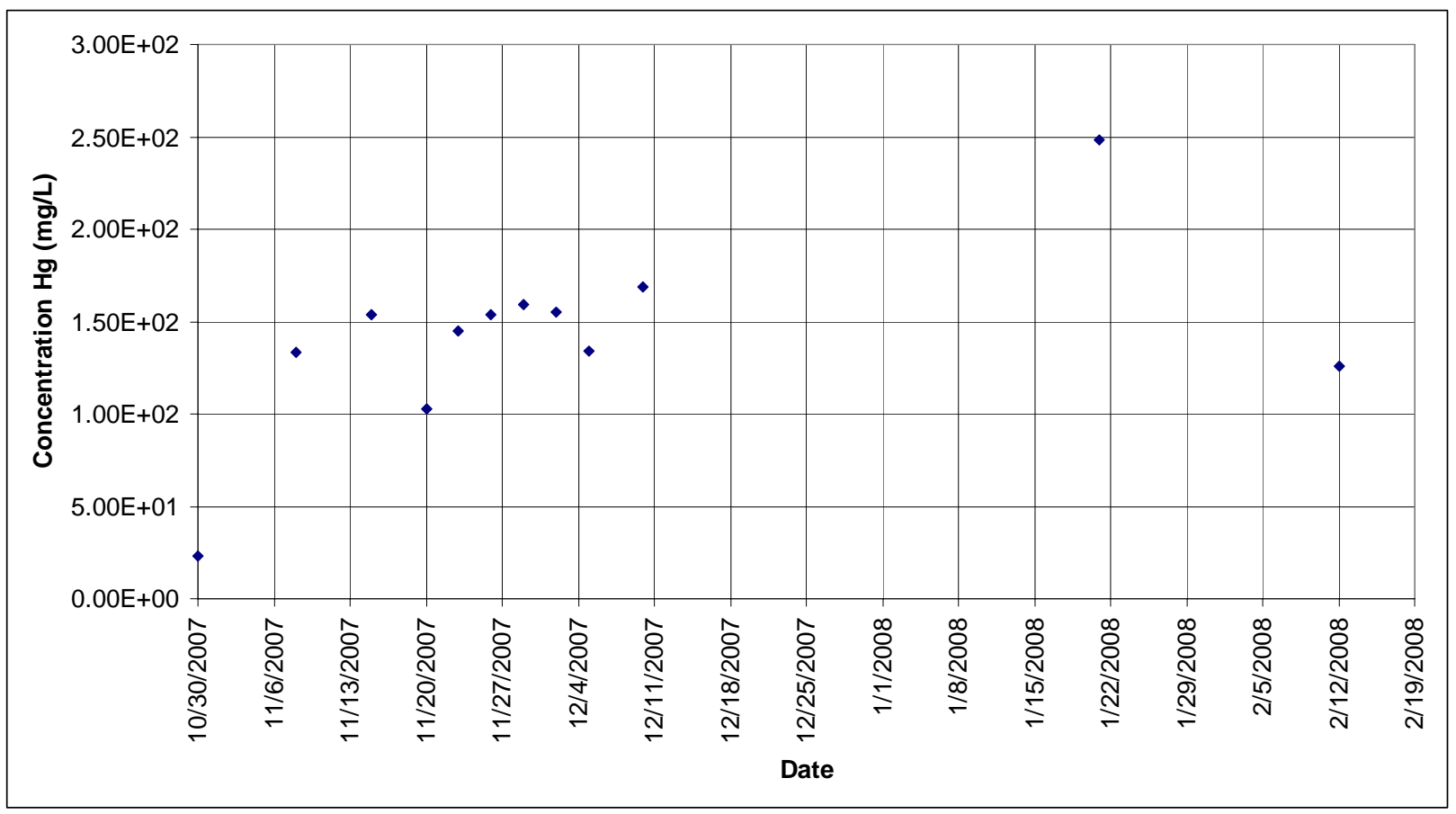

Figure 3: Change in Mercury Concentration During LTAD

\subsubsection{Zirconium}

Table 3 shows that zirconium content dramatically increased in the solid phase. However, the liquid phase concentration was at or below the detection limits. The liquid phase detection limit was reported at $1.2 \mathrm{mg} / \mathrm{L} .{ }^{11}$ The total zirconium content of the liquid phase even at the detection limit could not account for the increase in the solid phase. This result would seem to be an analytical anomaly, but LTAD in Tank 51 as well as in the laboratory demonstration of LTAD appear to have a similar increase. The inprocess samples show near or below detection limits for all samples so no trend can be established. Since 
the concentration in the solid phase is similar after LTAD and the lab-scale demonstration, the result from the sample before dissolution may be inaccurate.

\subsubsection{Technetium}

Examination of the lab-scale demonstration of LTAD and the in-tank data showed mixed results. During the lab-scale demonstration, technetium, represented by the changes in Tc-99 in Table 3, appeared to increase in the solid phase, but also showed an increase in the liquid phase content. In contrast, the intank sample results showed a moderate reduction in the solid phase. The change in liquid phase concentration is likely to be more accurate since the solid phase concentrations are derived from the difference between concentration in the slurry and concentration in the liquid and thereby prone to larger error. The liquid phase results show a moderate increase in total mass of dissolved technetium for both the lab-scale demonstration and LTAD in Tank 51. Figure 4 shows the change in concentration in the liquid phase. One should note that the small decrease in concentration shown in the figure represents a moderate increase in total technetium due to the increase in liquid phase volume from the caustic addition and pump bearing water leakage.

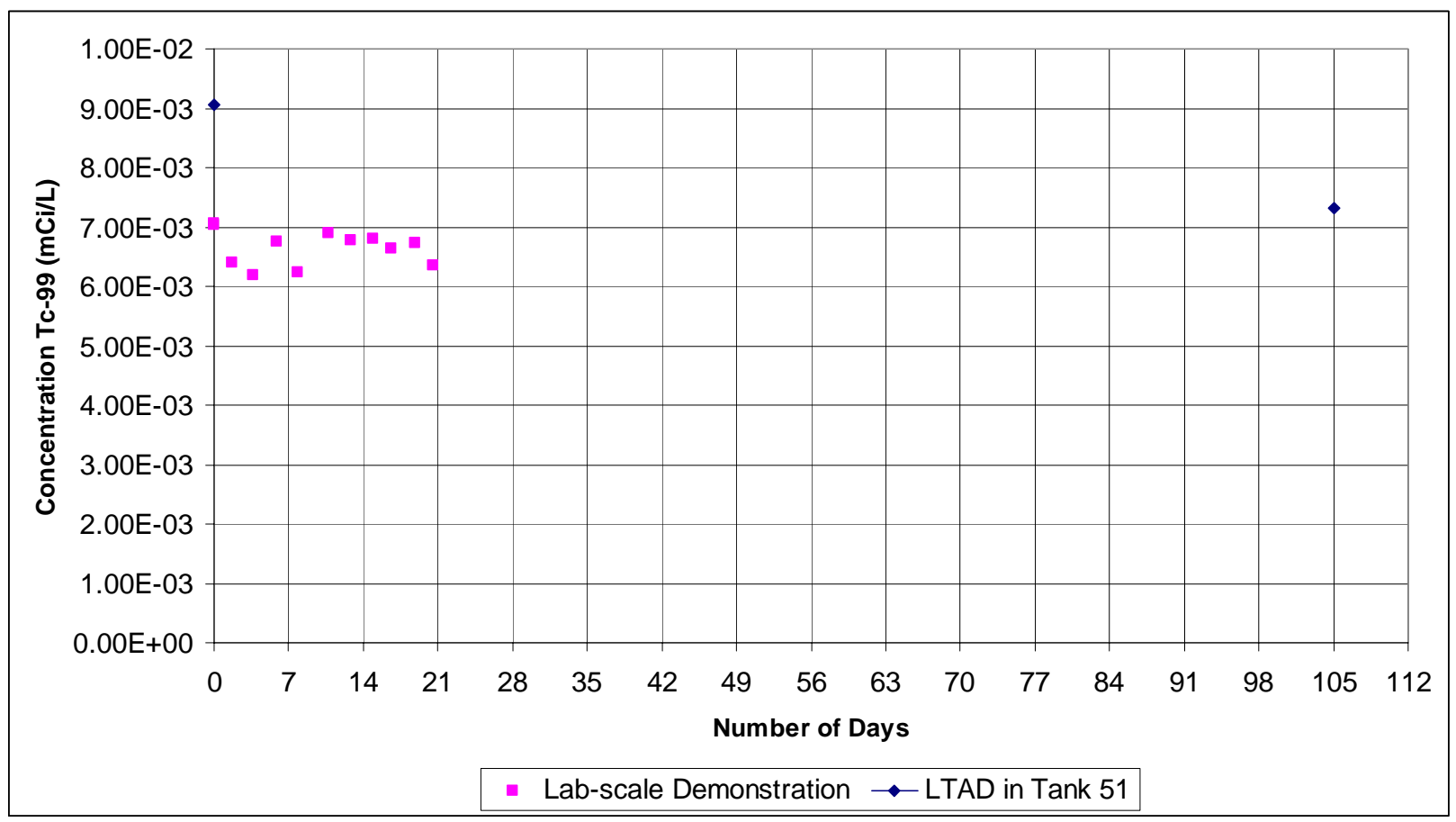

Figure 4: Change in Technetium Concentration During LTAD 
SRNS-STI-2008-00021

REVISION 0

Table 3: Characterization of Sludge Slurry Before and After LTAD ${ }^{11,13}$

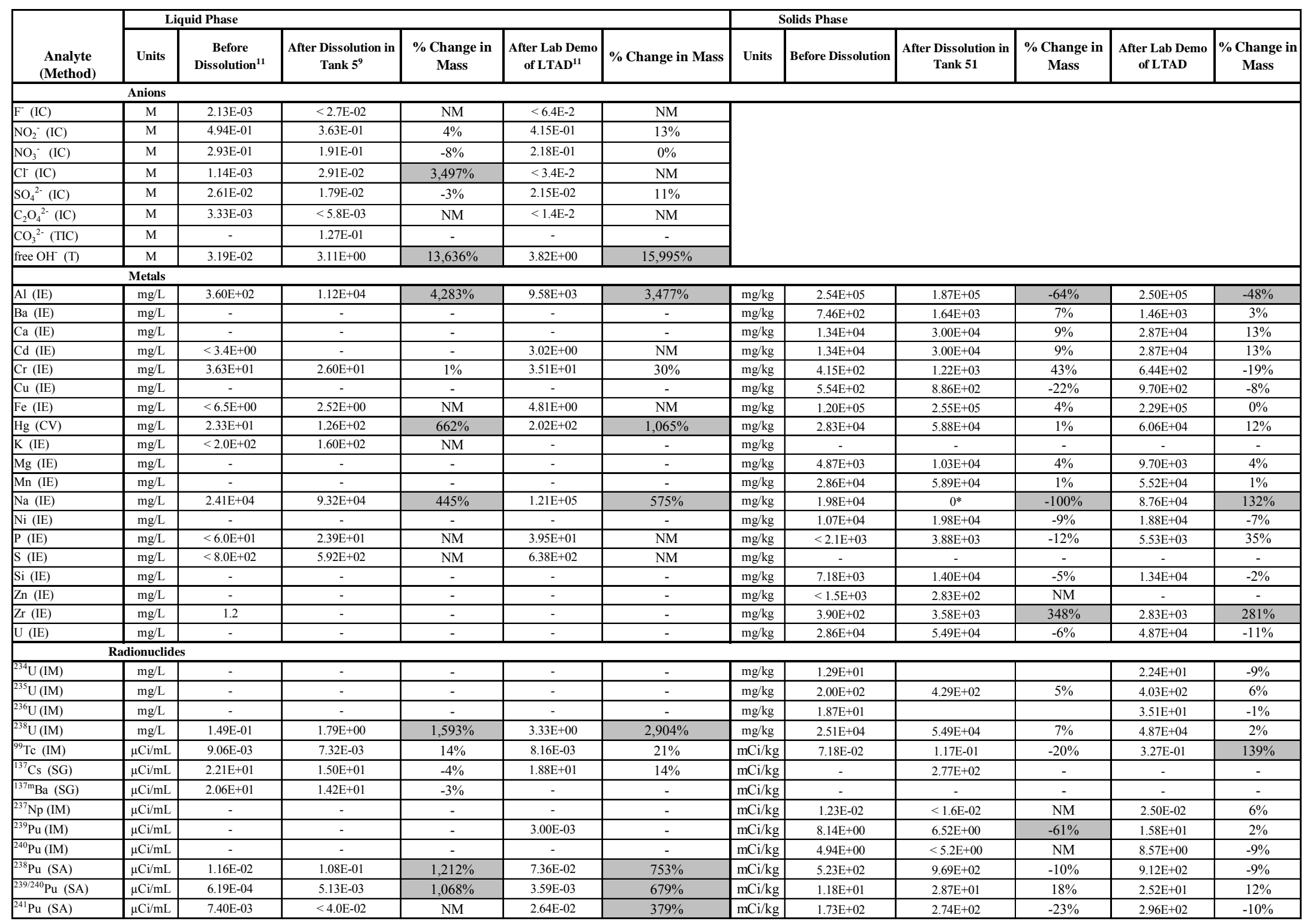

Page 13 of 33 


\section{Table Notes:}

* Value for sodium content actually was slightly less than zero, which is impossible. Since the value is derived by calculation of analytical data, the result likely indicates that practically all sodium originally in the solids went into solution, thus, 0 remains in the solid phase.

$\mathrm{NM}=$ not meaningful because detection limit after aluminum dissolution was higher than the measured value before aluminum dissolution or vice versa.

Liquid Phase Calculations:

$\%$ Change in mass $=\left([\mathrm{X}]_{1-\mathrm{f}} \cdot \mathrm{V}_{1-\mathrm{f}}-[\mathrm{X}]_{1-\mathrm{i}} \cdot \mathrm{V}_{1-\mathrm{i}}\right) /\left([\mathrm{X}]_{1-\mathrm{i}} \cdot \mathrm{V}_{\mathrm{l-i}}\right) \cdot 100$

where:

$\mathrm{V}_{\mathrm{l}}=\mathrm{V}_{\text {Total }}-\mathrm{V}_{\mathrm{s}}=$ inches tank level $\cdot 3510 \mathrm{gal} /$ inch $\cdot 3.7854 \mathrm{~L} / \mathrm{gal}\left(1-\rho_{\text {slurry }} \cdot \mathrm{wt}_{\mathrm{t}} \mathrm{s}_{\mathrm{s}} / \rho_{\mathrm{s}}\right)$

Solid Phase Calculations:

$\mathrm{wt} \%$ of $\mathrm{X}_{\text {insoluble solids }}=\left\{\mathrm{wt} \%_{\mathrm{x} \text { in total solids }} \cdot \mathrm{wt}_{\mathrm{t}} \%_{\text {total solids }}-[\mathrm{X}]_{1} \cdot \mathrm{wt} \%_{\text {soluble solids }} /\left(\mathrm{wt} \%_{\text {dissolved solids }} \cdot \rho_{1}\right)\right\} / \mathrm{wt} \%_{\text {insoluble solids }}$

$\%$ Change in mass $=\left([\mathrm{X}]_{\mathrm{s}-\mathrm{f}} \cdot \mathrm{m}_{\mathrm{s}-\mathrm{f}}-[\mathrm{X}]_{\mathrm{s}-\mathrm{i}} \cdot \mathrm{m}_{\mathrm{s}-\mathrm{i}}\right) /\left([\mathrm{X}]_{\mathrm{s}-\mathrm{i}} \cdot \mathrm{m}_{\mathrm{s}-\mathrm{i}}\right) \cdot 100$

where:

In Tank 51: $\mathrm{m}_{\mathrm{s}}=$ inches of tank level $\cdot 3510 \mathrm{gal} / \mathrm{inch} \cdot 3.7854 \mathrm{~L} / \mathrm{gal} \cdot \rho_{\text {slurry }} \cdot \mathrm{wt}^{\%} \mathrm{~s}_{\mathrm{s}}$

In Lab demo: $\mathrm{m}_{\mathrm{s}-\mathrm{i}}=$ reported slurry mass $\cdot \mathrm{wt} \%_{\mathrm{s}}$

In Lab demo final mass of each metal proportioned to Fe (Fe assumed insoluble): $[\mathrm{X}]_{\mathrm{s}-\mathrm{f}} \cdot \mathrm{m}_{\mathrm{s}-\mathrm{f}}=[\mathrm{X}]_{\mathrm{s}-\mathrm{f}} \cdot[\mathrm{Fe}]_{\mathrm{s}-\mathrm{i}} \cdot \mathrm{m}_{\mathrm{s}-\mathrm{i}} /[\mathrm{Fe}]_{\mathrm{s}-\mathrm{f}}$

Where:

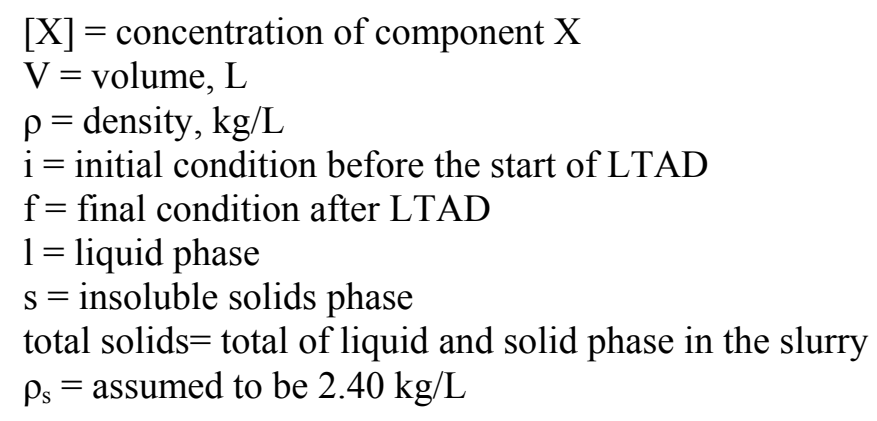




\subsection{Fate of Uranium and Plutonium}

A previous evaluation by Reboul ${ }^{14}$ before LTAD recommended measurement of uranium and plutonium isotopic concentrations as well as primary absorber metals in order to expand the limited knowledge of partitioning under conditions for aluminum dissolution. Analytical data was obtained from slurry samples before and after the LTAD in Tank 51 as well as during laboratory scale LTAD simulation on a sample from Tank 51. The previous evaluation examined two existing sources of data, the 1982 SRS aluminum dissolution demonstration ${ }^{9,15,16}$ and the 2001 PNNL Hanford sludge leaching tests. ${ }^{17}$ The additional data generated during the LTAD process are shown as highlighted rows in Table 4 through Table 7.

LTAD was run under different conditions and longer duration than the baseline aluminum dissolution process and several laboratory test. In all of these cases, caustic solutions were mixed with insoluble sludge solids and heated, with the objective of removing aluminum from the sludge phase. In the case of the PNNL activities, a second objective was to remove chromium from the sludge phase. The conditions of the dissolution activities are summarized in Table 4.

Table 4: Process Conditions Summary

\begin{tabular}{|l|c|c|c|c|}
\hline \multicolumn{1}{|c|}{ Organization } & $\begin{array}{c}\text { Sludge } \\
\text { Source }\end{array}$ & $\begin{array}{c}\text { Free Hydroxide } \\
\text { Concentration, } M\end{array}$ & Temperature, C & $\begin{array}{c}\text { Duration, } \\
\text { days }\end{array}$ \\
\hline \hline LTAD, 2007-2008 & Tk 11 & $4.1^{*}$ & $55-63$ & $46^{\#}$ \\
\hline LTAD Lab Demo, 2007 & Tk 11 & $4.3^{* *}$ & 55 & 21 \\
\hline SRS Demo, 1982 & Tk 15 & 3 & 85 & 7 \\
\hline PNNL Tests, 2001 & S-110 & 1,3 , and 5 & 60,80, and 100 & 7 \\
\hline
\end{tabular}

* Adequate concentrated sodium hydroxide was added to reach 4.1 M in tank, but free hydroxide measured in dip samples never exceeded $3.4 \mathrm{M}$.

** Estimated concentration. Actual concentration never measured. After dissolution free hydroxide measured at $3.82 \mathrm{M}$.

\# The duration of the dissolution during LTAD is calculated from the time of the last caustic addition to the initiation of sludge settling to decant the aluminum leach solution.

The previous evaluation identified minimal leaching of uranium and plutonium from the sludge. Analytical data generated during LTAD confirms the same result as shown in Table 5 even though plutonium concentration in the liquid phase was two to three times higher than previous aluminum dissolution results. The total mass of plutonium in solution was still a very small amount relative to the total mass in the sludge solids. LTAD in Tank 51 more than doubled the dissolution time of the laboratory demonstration, however, the plutonium concentration was nearly identical in both cases as shown in Table 6 . The previous evaluation did not identify any mechanism for the relatively low plutonium concentrations in the earlier aluminum dissolution demonstration and tests. Considering the much shorter duration of all previous tests, plutonium may not have reached equilibrium concentration. Note that the plutonium concentration remained within the range typically observed in liquid waste as shown in Table 1.

Table 6 also shows that the LTAD constituent concentrations are consistent with the results of the SRS aluminum dissolution demonstration in 1982 even though the dissolution temperature was much higher in the 1982 demonstration. These results are consistent with the conclusions of the previous evaluation in that the constituent concentrations are within the range of concentrations observed in SRS supernate. 
Note that the nitrate and nitrite ion concentrations are relatively low because LTAD was performed on sludge that was already washed of salt as part of the Sludge Batch 4 preparation.

Table 5: Proportions of Key Constituents Leached Out of Sludge

\begin{tabular}{|l|c|c|c|}
\hline \multirow{2}{*}{ Source of Data } & \multicolumn{3}{|c|}{ Proportion of Constituent Leached Out of Sludge, \% } \\
\cline { 2 - 4 } & Iron & Uranium & Plutonium \\
\hline \hline LTAD, 2007-2008 & $<0.03$ & 0.1 & $0.3-0.5$ \\
\hline LTAD Lab Demo, 2007 & 0.0003 & $0.1-0.2$ & $0.1-0.3$ \\
\hline SRS Demo, 1982 & $<0.1$ & $5-10$ & $0.2-0.4$ \\
\hline PNNL Tests, 2001 & $1-11$ & $2-7$ & $0.1-3$ \\
\hline
\end{tabular}

Table 6: Concentration of Key Constituents in Caustic Leachate and Supernatant Waste Solutions

\begin{tabular}{|l|c|c|c|c|c|c|c|c|c|}
\hline & \multicolumn{7}{|c|}{ Constituent Concentration } \\
\hline Waste Solution & $\begin{array}{c}\mathrm{OH}^{-}, \\
\mathrm{M}\end{array}$ & $\begin{array}{c}\mathrm{NO}_{3}^{-}, \\
\mathrm{M}\end{array}$ & $\begin{array}{c}\mathrm{NO}^{-}, \\
\mathrm{M}\end{array}$ & $\mathrm{Na}, \mathrm{mg} / \mathrm{L}$ & $\mathrm{Al}, \mathrm{mg} / \mathrm{L}$ & $\mathrm{Cr}, \mathrm{mg} / \mathrm{L}$ & $\mathrm{Fe}, \mathrm{mg} / \mathrm{L}$ & $\mathrm{U}, \mathrm{mg} / \mathrm{L}$ & $\begin{array}{c}\mathrm{Pu}, \\
\mathrm{mg} / \mathrm{L}\end{array}$ \\
\hline $\begin{array}{l}\text { LTAD caustic } \\
\text { leachate }\end{array}$ & 3.1 & 0.19 & 0.36 & $9 \mathrm{E}+4$ & $1 \mathrm{E}+4$ & $3 \mathrm{E}+1$ & $3 \mathrm{E} 0$ & $2 \mathrm{E} 0$ & $1 \mathrm{E}-1$ \\
\hline $\begin{array}{l}\text { LTAD lab demo } \\
\text { caustic leachate }\end{array}$ & 3.8 & 0.22 & 0.42 & $1 \mathrm{E}+5$ & $1 \mathrm{E}+4$ & $4 \mathrm{E}+1$ & $5 \mathrm{E} 0$ & $3 \mathrm{E} 0$ & $9 \mathrm{E}-2$ \\
\hline $\begin{array}{l}\text { SRS demo } \\
\text { caustic leachate }\end{array}$ & 3 & 1.2 & 0.3 & $1 \mathrm{E}+5$ & $2 \mathrm{E}+4$ & $4 \mathrm{E}+1$ & $2 \mathrm{E} 0$ & $3 \mathrm{E} 0$ & $4 \mathrm{E}-3$ \\
\hline $\begin{array}{l}\text { PNNL Tests, } \\
\text { caustic leachate }\end{array}$ & $1-5$ & $\mathrm{NR}$ & $\mathrm{NR}$ & $0.2 \mathrm{E}+5-$ & $2 \mathrm{E}+3-$ & $2 \mathrm{E}+2-$ & $0.2 \mathrm{E}+1-$ & $1 \mathrm{E}+1-$ & $0.3 \mathrm{E}-3$ \\
\hline $\begin{array}{l}\text { SRS Tk 13 } \\
\text { supernatant }\end{array}$ & 6 & 1.4 & 1.5 & $2 \mathrm{E}+5$ & $2 \mathrm{E}+4$ & $6 \mathrm{E}+2$ & $1 \mathrm{E}+1$ & $2 \mathrm{E} 0$ & $3 \mathrm{E}-2$ \\
\hline $\begin{array}{l}\text { SRS Tk 30 } \\
\text { supernatant }\end{array}$ & 7 & 1.5 & 2.0 & $3 \mathrm{E}+5$ & $2 \mathrm{E}+4$ & $4 \mathrm{E}+2$ & $2 \mathrm{E}+1$ & $5 \mathrm{E} 0$ & $2 \mathrm{E}-2$ \\
\hline $\begin{array}{l}\text { SRS Tk 37 } \\
\text { supernatant }\end{array}$ & 10 & 1.1 & 1.4 & $3 \mathrm{E}+5$ & $1 \mathrm{E}+4$ & $6 \mathrm{E}+2$ & $1 \mathrm{E}+1$ & $6 \mathrm{E} 0$ & $3 \mathrm{E}-2$ \\
\hline $\begin{array}{l}\text { SRS Tk 39 } \\
\text { supernatant }\end{array}$ & 3 & 2.5 & 0.5 & $1 \mathrm{E}+5$ & $1 \mathrm{E}+4$ & $1 \mathrm{E}+2$ & $1 \mathrm{E}+1$ & $6 \mathrm{E} 0$ & $7 \mathrm{E}-1$ \\
\hline $\begin{array}{l}\text { SRS Tk 45 } \\
\text { supernatant }\end{array}$ & 14 & 1.3 & 1.5 & $4 \mathrm{E}+5$ & $8 \mathrm{E}+3$ & $3 \mathrm{E}+1$ & $2 \mathrm{E}+1$ & $2 \mathrm{E} 0$ & $7 \mathrm{E}-2$ \\
\hline $\begin{array}{l}\text { SRS Tk 46 } \\
\text { supernatant }\end{array}$ & 8 & 1.8 & 1.9 & $3 \mathrm{E}+5$ & $2 \mathrm{E}+4$ & $2 \mathrm{E}+2$ & $4 \mathrm{E}+1$ & $7 \mathrm{E} 0$ & $3 \mathrm{E}-2$ \\
\hline $\begin{array}{l}\text { SRS Tk 49 } \\
\text { supernatant }\end{array}$ & 6 & 2.4 & 1.5 & $2 \mathrm{E}+5$ & $1 \mathrm{E}+4$ & $2 \mathrm{E}+2$ & $2 \mathrm{E}+1$ & $2 \mathrm{E} 0$ & $1 \mathrm{E}-2$ \\
\hline
\end{tabular}

$\mathrm{NR}=$ Not reported

Mass concentrations of fissile isotopes (U-233, U-235, Pu-239, and Pu-241) in the caustic leachate solutions are given in Table 7. Reboul identified the relative dominance of the fissile isotopes as: U-235 $>\mathrm{U}-233>\mathrm{Pu}-239>\mathrm{Pu}-241$ for the sludge slurry from the 1982 aluminum dissolution demonstration. In contrast, the isotopic distribution of uranium in the sludge slurry from LTAD has a much lower U-235 content. Combined with the higher plutonium content in the leachate, the order of dominance changes to: $\mathrm{Pu}-239>\mathrm{U}-235>\mathrm{Pu}-241>\mathrm{U}-233$. However, the concentration of Pu-239 and U-235 are on the same 
order of magnitude. In this case, U-235 is not the dominating driver of fissile content of the waste as was the case in the previous analysis.

Table 7: Concentrations of Fissile Uranium and Plutonium Isotopes in Caustic Leachate Solutions

\begin{tabular}{|l|c|c|c|c|}
\hline \multicolumn{1}{|c|}{ Waste Solution } & \multicolumn{4}{c|}{ Isotope Concentration, mg/L } \\
\hline & $\mathrm{U}-233$ & $\mathrm{U}-235$ & $\mathrm{Pu}-239$ & $\mathrm{Pu}-241$ \\
\hline \hline LTAD caustic leachate & $2 \mathrm{E}-4^{*}$ & $2 \mathrm{E}-2^{*}$ & $8 \mathrm{E}-2$ & $6 \mathrm{E}-3^{*}$ \\
\hline LTAD lab demo caustic leachate & $4 \mathrm{E}-4^{*}$ & $4 \mathrm{E}-2^{*}$ & $6 \mathrm{E}-2$ & $3 \mathrm{E}-4$ \\
\hline SRS demo caustic leachate & $1 \mathrm{E}-1$ & $2 \mathrm{E} 0$ & $3 \mathrm{E}-3$ & $1 \mathrm{E}-4$ \\
\hline PNNL test caustic leachate & NR & $1 \mathrm{E}-1-3 \mathrm{E}-1$ & $0.3 \mathrm{E}-3-6 \mathrm{E}-3$ & NR \\
\hline \multicolumn{7}{|c}{ NR $=$ Not reported }
\end{tabular}

* Concentration calculated based on isotopic mass distribution using isotopic mass data estimated in reference 1.

The relative ratios of neutron absorber masses to fissile material masses provide another means of characterizing the SRS and PNNL leachates. Based on the absorber concentrations given in Table 6 and the U-235 and Pu-239 concentrations given in Table 7, the mass ratios were identified as shown in Table 8.

Table 8: Absorber to Fissile Mass Ratios

\begin{tabular}{|c|c|c|c|c|c|c|}
\hline \multirow[t]{2}{*}{ Metal } & \multicolumn{2}{|c|}{$\begin{array}{c}\text { LTAD caustic } \\
\text { leachate }\end{array}$} & \multicolumn{2}{|c|}{$\begin{array}{c}\text { Lab Demo of } \\
\text { LTAD caustic } \\
\text { leachate }\end{array}$} & \multirow{2}{*}{$\begin{array}{c}\begin{array}{c}\text { SRS Demo, } \\
\text { caustic } \\
\text { leachate }\end{array} \\
\text { U-235* }\end{array}$} & \multirow{2}{*}{$\begin{array}{c}\begin{array}{c}\text { PNNL Tests, } \\
\text { caustic leachate }\end{array} \\
\text { U-235* } \\
\end{array}$} \\
\hline & U-235 & Pu-239 & U-235 & Pu-239 & & \\
\hline $\mathrm{Na}$ & $6^{4 \mathrm{E}+0}$ & $3^{7 \mathrm{E}+0}$ & $3 \mathrm{E}+06$ & $9 \mathrm{E}+03$ & $1 \mathrm{E}+05$ & $1 \mathrm{E}+5$ to $1 \mathrm{E}+6$ \\
\hline $\mathrm{Al}$ & $5^{5 \mathrm{E}+0}$ & 900 & $2 \mathrm{E}+05$ & 700 & $1 \mathrm{E}+04$ & $1 \mathrm{E}+4$ to $1 \mathrm{E}+5$ \\
\hline $\mathrm{Cr}$ & $3^{1 \mathrm{E}+0}$ & 2 & 800 & 3 & 10 & $1 \mathrm{E}+03$ \\
\hline $\mathrm{Fe}$ & 100 & 0.2 & 100 & 0.4 & 1 & 10 to 100 \\
\hline
\end{tabular}

* Only U-235 concentration was used since it dominated the other fissile isotope concentrations.

\subsection{Metals Summary}

Aluminum dissolution at moderately lower temperatures and longer dissolution times resulted in dissolution of metals consistent with previous experience. Other than aluminum, the metals that leached from the sludge solids include mercury, uranium, and plutonium. Plutonium dissolved from the sludge resulting in a concentration two to three times higher than observed in the 1982 aluminum dissolution demonstration. The shorter duration of the 1982 demonstration may not have allowed the plutonium to reach equilibrium concentrations.

As a fraction of the sludge solids, well less than $1 \%$ of the solids other than aluminum dissolved.

The sample results suggested some dissolution of technetium, but the observed increase in liquid phase composition, $14-21 \%$, was only somewhat larger than the relative standard deviation reported with the 
analytical results, $4-12 \%$ and the total sampling variability is likely to be higher, thus, the apparent increase may not be real.

The 1982 demonstration observed possible dissolution of chromium, however, little or no chromium dissolved during LTAD.

Caustic addition added significantly to the existing chloride in the waste. Future aluminum dissolution should track the chloride concentration to avoid reaching chloride concentrations that may affect stainless steel corrosion or impact downstream processes.

\section{TANK HEAT LOSS}

When planning LTAD, determining the rate of temperature increase using slurry pumps as heat input was hindered by the lack of reasonable estimate of the rate of heat loss. During LTAD, tank cooling and annulus ventilation were off. An opportunity to estimate heat loss was anticipated when the process entered into the settling phase, but an additional opportunity was created during a pump outage before the dissolution phase was complete. The objective of this heat loss evaluation is to create an approximation method for planning future aluminum dissolution. Effectively, the need is to estimate the rate of temperature change on a daily basis for any aluminum dissolution batch. Indirectly meeting this objective also would allow estimation of rate of temperature increase for a given energy source.

\subsection{Generalized Heat Loss Model}

Energy transfer in a waste tank is relatively complex because pathways include convection through the sidewall, conduction through the bottom and energy loss via evaporation through the purge ventilation system. Furthermore, the vapor space creates a complex convection, evaporation, and condensation cycle where energy will transfer between the waste surface and vapor space and the vapor space can transfer energy through the sidewall via convection and condensation. Furthermore, the waste layers of sludge and supernate form an additional interface where the settled sludge layer transfers energy through the wall and bottom by conduction because the yield stress of the sludge prevents convection. The annular space will be in steady state between the sludge, liquid, and vapor layers. Since the sludge layer becomes the warmest layer, the annulus readily forms a natural convective current even without forced ventilation. The energy transfer is likely limited by the rate of conduction between the annulus wall and the ground surrounding the tank. Forced ventilation in the annulus increases the energy transfer rates. The cooling coils create a similar complex heat transfer mechanism inside the tank between the cooling water and the three layers inside the tank, but when the cooling coils are off, this pathway becomes zero. The cooling coils can become heat conductors that increase the energy transfer between the layers.

The objective for this evaluation does not require a great deal of precision, so only the dominant heat transfer pathways were considered. The heat transfer mechanism is grossly simplified by assuming that energy loss by natural convection through the sidewalls and conduction through the tank bottom dominate. Energy loss by evaporated water vapor via the tank purge ventilation is assumed to be small compared to the over all heat loss. Aluminum dissolution is an endothermic reaction, but the rate of energy consumed by the reaction during these tank quiescent periods is assumed to be small relative to the heat transfer pathways. The overall simplified energy flow in or out of the tank may be approximated as:

$$
\mathrm{q}=\mathrm{U} \cdot \mathrm{A} \cdot \mathrm{dT}
$$


where

$\mathrm{q}=$ total energy flow, $\mathrm{cal} / \mathrm{hr}$,

$\mathrm{U}=$ over all heat transfer coefficient, cal $/ \mathrm{hr} / \mathrm{m}^{2} / \mathrm{K}$

$\mathrm{A}=$ heat transfer surface area, $\mathrm{m}^{2}$, and

$\mathrm{T}=$ temperature, thus, $\mathrm{dT}$ is differential temperature between the waste and the heat sink, either annulus air temperature or ground.

If this simplification is reasonable, then it suggests that an overall energy transfer coefficient may be estimated for tank heat loss when quiescent. In this case, the area for heat transfer is assumed to be the entire sidewall and bottom. As such, the area is fixed by the tank dimensions, thus, the term $\mathrm{U} \cdot \mathrm{A}$ is constant.

\subsection{Tank Temperature Change}

Temperature of the sludge slurry and supernate layers may be determined over time using the abundant data available from thermocouples in Risers D2, D3, and D4 at the elevations shown in Table 9. One might note that the distribution of elevations is approximately every foot in elevation for the first 192", which was the maximum level reached during LTAD. During a quiescent period, the supernate layer forms as the sludge settles. The sludge supernate interface was measured and the settling equation fit to the data such that the interface level may be determined at practically any time during the quiescent period. $^{18}$

The supernate temperature is determined by the dominant temperature measured by all thermocouples in the supernate layer. An equivalent determination can be done for the sludge layer. One may note that the sludge layer temperature may be more difficult to determine because the dominant energy transfer pathway is by conduction. As such, temperature gradients form after a few days of settling and continuously change as the insoluble solids in the sludge layer becomes more concentrated.

Table 10 shows the temperature of each layer at 8:00 a.m. each day. Data is available at a substantially higher frequency; however, a daily frequency is all that is needed to determine overall energy transfer. The rate of temperature change is sufficiently slow that several days are needed to establish a trend and weeks are needed to determine a reasonable rate of heat loss. As such, the additional data would likely introduce more analytical noise. Note that the method to determine the temperature for each layer as described above is time consuming as care must be taken to examine the temperature at each riser and elevation to determine which layer affects the temperature reading of the thermocouple at each time record.

Table 10 also shows the slurry interface level as determined by the sludge settling model with parameters fit to the settling data after LTAD. ${ }^{18}$ The liquid above the interface is the supernate layer. Volume of the sludge slurry is calculated by multiplying the sludge slurry interface elevation by the Tank 51 calibration of $3510 \mathrm{gal} / \mathrm{inch}$. The supernate volume is the difference from the top of the waste and the sludge slurry interface multiplied by the tank calibration. The mass average temperature is determined as follows:

$$
\mathrm{T}_{\text {avg }}=\left(\mathrm{T}_{\text {supernate }} \cdot \mathrm{V}_{\text {supernate }} \cdot \rho_{\text {supernate }}+\mathrm{T}_{\text {sludge }} \cdot\left[\left(\mathrm{V}_{\text {sludge }}-\mathrm{V}_{\mathrm{s}}\right) \cdot \rho_{\text {supernate }}+\mathrm{V}_{\mathrm{s}} \cdot \rho_{\mathrm{s}}\right]\right) / \mathrm{M}
$$

where:

$$
\begin{aligned}
& \mathrm{M}=\mathrm{V}_{\text {supernate }} \cdot \rho_{\text {supernate }}+\left[\left(\mathrm{V}_{\text {sludge }}-\mathrm{V}_{\mathrm{s}}\right) \cdot \rho_{\text {supernate }}+\mathrm{V}_{\mathrm{s}} \cdot \rho_{\mathrm{s}}\right], \\
& \mathrm{avg}=\text { mass weighted average, } \\
& \mathrm{T}=\text { Temperature, and }
\end{aligned}
$$


$\mathrm{V}=$ Volume

Table 9: Thermocouple Distribution in Tank 51

\begin{tabular}{|l|l|}
\hline Riser & $\begin{array}{l}\text { Elevation from } \\
\text { Tank Bottom } \\
\text { (inches) }\end{array}$ \\
\hline D2 & 216 \\
& 168 \\
& 132 \\
& 96 \\
& 48 \\
& 18 \\
& 3 \\
\hline D3 & 240 \\
& 180 \\
& 144 \\
& 108 \\
& 60 \\
& 24 \\
& 9 \\
\hline D4 & 260 \\
& 192 \\
& 156 \\
& 120 \\
& 72 \\
& 36 \\
& 12 \\
\hline
\end{tabular}


SRNS-STI-2008-00021

REVISION 0

Table 10: Temperature and Energy Change in Tank 51

\begin{tabular}{|c|c|c|c|c|c|c|c|c|}
\hline Date & $\begin{array}{l}\text { Time } \\
\text { (days) }\end{array}$ & $\begin{array}{l}\text { Sludge } \\
\text { Slurry } \\
\text { Level } \\
\text { (inches) }\end{array}$ & $\begin{array}{c}\text { Sludge } \\
\text { Slurry } \\
\text { Volume (gal) }\end{array}$ & \begin{tabular}{|c|} 
Supernate \\
Layer \\
Volume (gal)
\end{tabular} & \begin{tabular}{|c|} 
Sludge \\
Temperature ( \\
C )
\end{tabular} & \begin{tabular}{|c|} 
Supernate \\
Temperature ( \\
C )
\end{tabular} & $\begin{array}{c}\text { Mass Average } \\
\text { Temperature } \\
\text { ( C ) }\end{array}$ & $\begin{array}{l}\text { Total Energy } \\
\text { Flow (cal/hr) }\end{array}$ \\
\hline \multicolumn{9}{|l|}{ Pump Outage } \\
\hline $12 / 10 / 2007$ & 0 & 189.7 & 666,000 & 0 & 62 & 62 & 62.0 & 0 \\
\hline $12 / 11 / 2007$ & 1 & 146.2 & 513,000 & 153,000 & 62 & 59 & 61.3 & $-96,000,000$ \\
\hline $12 / 12 / 2007$ & 2 & 131.9 & 463,000 & 203,000 & 62 & 57 & 60.5 & $-104,000,000$ \\
\hline $12 / 13 / 2007$ & 3 & 123.1 & 432,000 & 234,000 & 62 & 57 & 60.3 & $-85,000,000$ \\
\hline $12 / 14 / 2007$ & 4 & 116.8 & 410,000 & 256,000 & 62 & 57 & 60.1 & $-74,000,000$ \\
\hline $12 / 15 / 2007$ & 5 & 111.8 & 392,000 & 274,000 & 62 & 56 & 59.6 & $-76,000,000$ \\
\hline $12 / 16 / 2007$ & 6 & 107.6 & 378,000 & 288,000 & 63 & 55 & 59.6 & $-67,000,000$ \\
\hline $12 / 17 / 2007$ & 7 & 104.1 & 366,000 & 300,000 & 63 & 55 & 59.5 & $-63,000,000$ \\
\hline $12 / 18 / 2007$ & 8 & 101.1 & 355,000 & 311,000 & 63 & 54 & 58.9 & $-66,000,000$ \\
\hline $12 / 19 / 2007$ & 9 & 98.4 & 345,000 & 320,000 & 63 & 53 & 58.3 & $-68,000,000$ \\
\hline $12 / 20 / 2007$ & 10 & 96.0 & 337,000 & 329,000 & 63 & 53 & 58.1 & $-65,000,000$ \\
\hline $12 / 21 / 2007$ & 11 & 93.8 & 329,000 & 337,000 & 63 & 53 & 58.0 & $-62,000,000$ \\
\hline $12 / 22 / 2007$ & 12 & 91.8 & 322,000 & 344,000 & 63 & 52 & 57.4 & $-65,000,000$ \\
\hline $12 / 23 / 2007$ & 13 & 90.0 & 316,000 & 350,000 & 62 & 52 & 56.8 & $-66,000,000$ \\
\hline $12 / 24 / 2007$ & 14 & 189.7 & 666,000 & 0 & 55 & 55 & 55.0 & $-76,000,000$ \\
\hline & & & & & & & Average & $-74,000,000$ \\
\hline \multicolumn{9}{|c|}{ Sludge Settling Period } \\
\hline $1 / 4 / 2008$ & 0 & 192.0 & 674,000 & 0 & 63 & 63 & 63.0 & 0 \\
\hline $1 / 5 / 2008$ & 1 & 146.6 & 515,000 & 159,000 & 63 & 59 & 62.1 & $-125,000,000$ \\
\hline $1 / 6 / 2008$ & 2 & 132.1 & 464,000 & 210,000 & 64 & 57 & 61.9 & $-87,000,000$ \\
\hline $1 / 7 / 2008$ & 3 & 123.3 & 433,000 & 241,000 & 64 & 57 & 61.5 & $-77,000,000$ \\
\hline $1 / 8 / 2008$ & 4 & 116.9 & 410,000 & 264,000 & 64 & 57 & 61.3 & $-70,000,000$ \\
\hline $1 / 9 / 2008$ & 5 & 111.8 & 393,000 & 281,000 & 64 & 56 & 60.7 & $-74,000,000$ \\
\hline $1 / 10 / 2008$ & 6 & 107.7 & 378,000 & 296,000 & 64 & 55 & 60.1 & $-76,000,000$ \\
\hline $1 / 11 / 2008$ & 7 & 104.2 & 366,000 & 308,000 & 64 & 55 & 60.0 & $-71,000,000$ \\
\hline $1 / 12 / 2008$ & 8 & 101.1 & 355,000 & 319,000 & 64 & 54 & 59.3 & $-73,000,000$ \\
\hline $1 / 13 / 2008$ & 9 & 98.4 & 346,000 & 328,000 & 64 & 54 & 59.2 & $-69,000,000$ \\
\hline $1 / 14 / 2008$ & 10 & 96.0 & 337,000 & 337,000 & 64 & 53 & 58.6 & $-72,000,000$ \\
\hline $1 / 15 / 2008$ & 11 & 93.8 & 329,000 & 345,000 & 64 & 53 & 58.5 & $-68,000,000$ \\
\hline $1 / 16 / 2008$ & 12 & 91.8 & 322,000 & 352,000 & 63 & 52 & 57.4 & $-75,000,000$ \\
\hline $1 / 17 / 2008$ & 13 & 90.0 & 316,000 & 358,000 & 62 & 52 & 56.8 & $-75,000,000$ \\
\hline $1 / 18 / 2008$ & 14 & 88.3 & 310,000 & 364,000 & 62 & 51 & 56.2 & $-76,000,000$ \\
\hline $1 / 19 / 2008$ & 15 & 86.7 & 304,000 & 370,000 & 61 & 50 & 55.1 & $-81,000,000$ \\
\hline $1 / 20 / 2008$ & 16 & 85.2 & 299,000 & 375,000 & 61 & 49 & 54.4 & $-81,000,000$ \\
\hline $1 / 21 / 2008$ & 17 & 83.8 & 294,000 & 380,000 & 60 & 48 & 53.3 & $-85,000,000$ \\
\hline $1 / 22 / 2008$ & 18 & 82.5 & 289,000 & 384,000 & 60 & 47 & 52.7 & $-85,000,000$ \\
\hline $1 / 23 / 2008$ & 19 & 81.2 & 285,000 & 389,000 & 59 & 46 & 51.6 & $-88,000,000$ \\
\hline $1 / 24 / 2008$ & 20 & 80.0 & 281,000 & 393,000 & 58 & 46 & 51.1 & $-88,000,000$ \\
\hline $1 / 25 / 2008$ & 21 & 78.9 & 277,000 & 397,000 & 57 & 45 & 50.0 & $-90,000,000$ \\
\hline $1 / 26 / 2008$ & 22 & 77.8 & 273,000 & 401,000 & 56 & 45 & 49.6 & $-89,000,000$ \\
\hline $1 / 27 / 2008$ & 23 & 76.8 & 270,000 & 404,000 & 56 & 44 & 48.9 & $-90,000,000$ \\
\hline $1 / 28 / 2008$ & 24 & 75.8 & 266,000 & 408,000 & 55 & 44 & 48.5 & $-89,000,000$ \\
\hline $1 / 29 / 2008$ & 25 & 74.9 & 263,000 & 411,000 & 55 & 43 & 47.8 & $-89,000,000$ \\
\hline $1 / 30 / 2008$ & 26 & 73.9 & 260,000 & 414,000 & 55 & 43 & 47.7 & $-87,000,000$ \\
\hline & & & & & & & Average & $-79,000,000$ \\
\hline \multicolumn{9}{|c|}{ Sludge Settling Period After Cooling Coils Turned on } \\
\hline $1 / 31 / 2008$ & 27 & 73.1 & 256,000 & 417,000 & 54 & 38 & 44.2 & $-400,000,000$ \\
\hline $2 / 1 / 2008$ & 28 & 72.2 & 253,000 & 420,000 & 54 & 32 & 40.5 & $-420,000,000$ \\
\hline $2 / 2 / 2008$ & 29 & 71.4 & 251,000 & 423,000 & 49 & 25 & 34.2 & $-520,000,000$ \\
\hline $2 / 3 / 2008$ & 30 & 70.6 & 248,000 & 426,000 & 49 & 24 & 33.5 & $-410,000,000$ \\
\hline $2 / 4 / 2008$ & 31 & 69.9 & 245,000 & 429,000 & 49 & 24 & 33.4 & $-340,000,000$ \\
\hline $2 / 5 / 2008$ & 32 & 69.1 & 243,000 & 431,000 & 48 & 23 & 32.3 & $-300,000,000$ \\
\hline $2 / 6 / 2008$ & 33 & 68.4 & 240,000 & 434,000 & 48 & 23 & 32.2 & $-270,000,000$ \\
\hline $2 / 7 / 2008$ & 34 & 67.7 & 238,000 & 436,000 & 47 & 22 & 31.1 & $-250,000,000$ \\
\hline $2 / 8 / 2008$ & 35 & 67.0 & 235,000 & 439,000 & 47 & 22 & 31.0 & $-230,000,000$ \\
\hline $2 / 9 / 2008$ & 36 & 66.4 & 233,000 & 441,000 & 46 & 22 & 30.6 & $-210,000,000$ \\
\hline $2 / 10 / 2008$ & 37 & 65.7 & 231,000 & 443,000 & 46 & 21 & 29.8 & $-200,000,000$ \\
\hline $2 / 11 / 2008$ & 38 & 65.1 & 229,000 & 445,000 & 45 & 21 & 29.4 & $-190,000,000$ \\
\hline $2 / 12 / 2008$ & 39 & & & & 29 & 29 & 29.0 & $-180,000,000$ \\
\hline
\end{tabular}

Page 21 of 33 
Figure 5 shows the average tank temperature, $T_{\text {avg }}$, for both quiescent periods. Each period started nearly at the same temperature. Both periods exhibit practically identical cooling rates, which indicate that the method is reproducible. The linear nature of the rate of temperature decay suggests that:

- the temperature of the heat sink is much lower than the waste temperature through the entire period,

- the sink temperature is roughly the same in December through February, and

- the sink temperature appears constant over several weeks.

This appears to be consistent with the ground as a heat sink rather than the air in the annulus, which exchanges with the ambient air by natural barometric breathing. Ambient air temperature had a large variation over the same months.

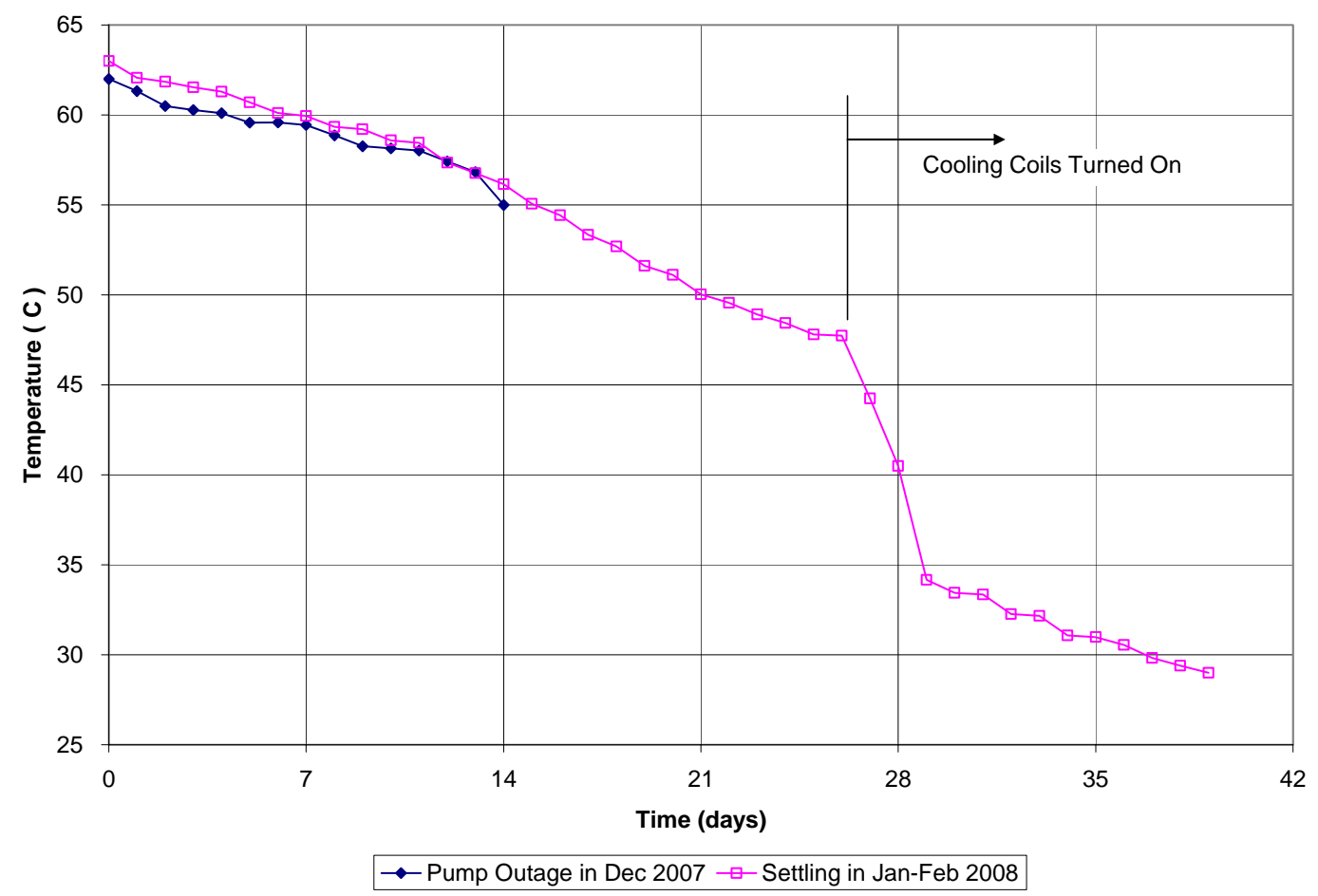

Figure 5: Overall Average Tank Temperature During Quiescent Periods

\subsection{Estimating Heat Capacity of Sludge and Supernate Layers}

The heat capacity of the liquid and sludge solids can be estimated using OLI Stream Analyzer ${ }^{\mathrm{tm}}$. Table 11 shows the results of the heat capacity estimate based on the composition of the after LTAD 3 L sample in addition to other physical parameters needed to complete the energy balance. 
SRNS-STI-2008-00021

REVISION 0

Table 11: Physical Parameters of Tank 51 Sludge Slurry During Quiescent Periods

\begin{tabular}{|l|r|l|}
\hline \multicolumn{1}{|c|}{ Paramater } & \multicolumn{1}{c|}{ Value } & \multicolumn{1}{c|}{ Basis } \\
\hline Sludge Heat Capacity $(\mathrm{cal} / \mathrm{g} / \mathrm{K})$ & 0.277 & Estimated using OLI Stream Analyzer $^{\text {tm }}$ \\
\hline Sludge Solids Density $(\mathrm{kg} / \mathrm{L})$ & 2.40 & Assumed density \\
\hline Supernate Heat Capacity $(\mathrm{cal} / \mathrm{g} / \mathrm{K})$ & 0.886 & Estimated using OLI Stream Analyzer \\
\hline Supernate Density $(\mathrm{kg} / \mathrm{L})$ & 1.15 & Measured from 3 L after LTAD sample \\
\hline Sludge Mass $(\mathrm{kg})$ & 92,500 & $\begin{array}{l}\text { Calculated using 3 L after LTAD } \\
\text { sample results }\end{array}$ \\
\hline Sludge Solids Volume (gal) & 10,200 & $\begin{array}{l}\text { Calculated based on assumed density of } \\
\text { sludge solids }\end{array}$ \\
\hline $\begin{array}{l}\text { Total Heat Generation In Sludge } \\
\text { during LTAD }(\mathrm{cal} / \mathrm{hr})\end{array}$ & $23,000,000$ & Based on WCS from 7/24/07 \\
\hline
\end{tabular}

\subsection{Estimating Energy Flow}

Total energy flow rate is calculated each day by totaling the change in sensible heat due to temperature change since the beginning of the period divided by the time since the beginning of the period and adding the heat generation rate due to energy deposition from radioactive decay. The change in energy for each layer is calculated separately and then the two results are added together to get the total change. Each layer is calculated separately because the heat capacity of the solid phase is different from the heat capacity of the liquid phase and the size of each layer changes with time. Regardless, the temperature measurements are recorded to the nearest whole integer value. The step change of one degree is not, in itself, large, but the change in energy for the mass of waste is large. The average rate of change depicted in Figure 5 without cooling coils in operation is $0.57^{\circ} \mathrm{C}$ per day. The step changes may occur one day, but not the next, resulting in unrealistic heat flows one day and very little the next. By calculating the cumulative change from the start of the period, the energy flow rate averages what otherwise looks like wild spikes. Therefore, the energy flow in Table 10 is calculated by summing the energy flow from each layer and the decay energy as follows:

$$
\begin{aligned}
& \mathrm{q}_{\text {total }}=\mathrm{q}_{\text {sludge }}+\mathrm{q}_{\text {supernate }}+\mathrm{q}_{\text {decay }} \\
& \mathrm{q}_{\text {sludge }}=\left[\left(\mathrm{C}_{\mathrm{p} \text {-supernate }} \cdot\left(\mathrm{V}_{\text {sludge }}-\mathrm{V}_{\mathrm{s}}\right) \cdot \rho_{\text {supernate }}+\mathrm{C}_{\mathrm{p} \text {-s }} \cdot \mathrm{m}_{\mathrm{s}}\right] \cdot\left(\mathrm{T}_{\text {sludge }}-\mathrm{T}_{\mathrm{i} \text {-sludge }}\right) / \mathrm{t}\right. \\
& \mathrm{q}_{\text {supernate }}=\mathrm{C}_{\mathrm{p} \text {-supernate }} \cdot \mathrm{V}_{\text {supernate }} \cdot \rho_{\text {supernate }} \cdot\left(\mathrm{T}_{\text {supernate }}-\mathrm{T}_{\mathrm{i} \text {-supernate }}\right) / \mathrm{t}
\end{aligned}
$$

Where:

$$
\begin{aligned}
& \mathrm{C}_{\mathrm{p}}=\text { heat capacity, cal } / \mathrm{g} / \mathrm{K}, \\
& \mathrm{s}=\text { insoluble solids, } \\
& \text { sludge = sludge layer, } \\
& \text { supernate = supernate layer, } \\
& \text { decay = energy generated from radioactive decay, and } \\
& \mathrm{t}=\text { time since start of the period, hours. }
\end{aligned}
$$

Figure 6 depicts the rate of heat transfer estimated by this method. Note that in both cases, the heat flow spikes in the first couple of days. This phenomenon is likely due to the initial formation of the settled sludge layer that does not support convective currents. At the very start of the settling period, the entire waste content is well slurried and flows easily. As the fraction of solids build in the slurry layer, 
eventually the slurry layer yield stress grows to a point where convective flow stops, reducing heat flow rate. Since this is relatively short lived, it does not significantly change the overall heat transfer rate.

One other phenomenon to note is that the heat flow rate steadily increases during the longer quiescent period. The supernate layer supports convective currents and the supernate layer is increasing during this time. However, the rate of increase in the supernate layer decreases with time, so the increasing rate of heat transfer does not correlate well. Another explanation for the effect would suggest that natural convection in such a large tank requires weeks to reach a steady state condition. The increase over time could also be an artifact of determining a bulk average temperature for each layer whereas the actual layer has significant temperature gradients that develop over time. The early heat flow may be artificially low because the method may not adequately capture the change in energy content of each layer until the bulk middle temperature is affected. The effect amounts to roughly a $20 \%$ change in rate during the period. A detailed model evaluation would likely reveal the mechanism causing this observation. For the purposes of this evaluation, this effect becomes part of the overall error of the method.

Temperature change appears to be practically linear during each quiescent period. Therefore, the heat loss is nearly constant. As a result, $\mathrm{q} / \mathrm{dT}$ is not constant. If the overall heat transfer assumption was reasonable, the expectation is that $\mathrm{q}$ would be a linear function of dT, i.e., $\mathrm{q} / \mathrm{dT}$ is constant. A 3dimensional heat transfer analysis would likely reveal the nature of the heat loss. Regardless, for planning purposes, the rate of heat loss can be approximated at $8 \mathrm{E}+7 \mathrm{cal} / \mathrm{hr}$.

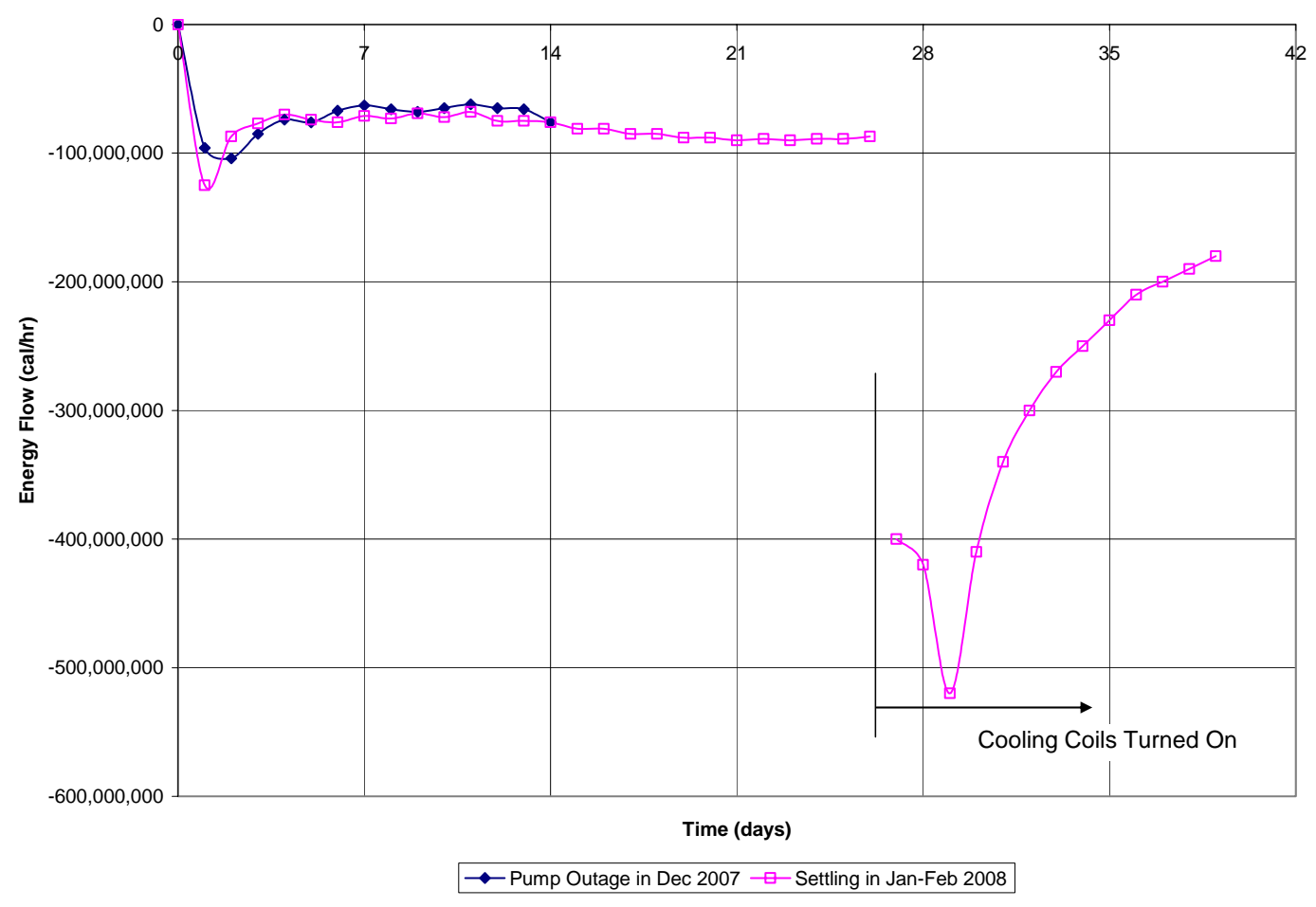

Figure 6: Heat Flow During Quiescent Periods 


\subsection{Predicting Rate of Temperature Change}

The heat loss and temperature loss were shown to be very close to linear during the quiescent periods. Table 10 shows that the tank temperature decreased $8^{\circ} \mathrm{C}$ in the first 14 days or $0.57^{\circ} \mathrm{C} /$ day in both periods and $15.3^{\circ} \mathrm{C}$ in 26 days or $0.59^{\circ} \mathrm{C} /$ day for the longer period. For any batch with similar heat generation rates due to radioactive decay, the temperature decay during settling may be estimated at $0.6^{\circ} \mathrm{C} /$ day. This sludge slurry generates heat at a rate of about $1 / 4$ of the rate of heat loss. If there was no heat generation in the waste, the rate of temperature change would be about $0.8^{\circ} \mathrm{C} /$ day. The rate of temperature change may be adjusted to account for variation in heat generation rates of a sludge slurry.

In order to estimate the rate of temperature increase during heating, the rate of energy input needs to be estimated. A prediction for the rate of temperature increase using the estimated heat loss determined in this evaluation is made for two cases. The predicted rate of temperature change is compared to actual observations.

The full-scale 1982 aluminum dissolution demonstration supplied $6000 \mathrm{lb} / \mathrm{hr}$ steam during tank heating and $1000 \mathrm{lb} / \mathrm{hr}$ was used to maintain the tank temperature between 83 and $85^{\circ} \mathrm{C}^{2}$ Presumably, the steam was supplied at $150 \mathrm{psi}$ since that is the commonly available steam source at the tank top. The reference is not clear on this point. Assuming $150 \mathrm{psi}$ steam, the steam supplies about $1141 \mathrm{btu} / \mathrm{lb}(1194 \mathrm{btu} / \mathrm{lb}$ as steam at $150 \mathrm{psi}-53 \mathrm{btu} / \mathrm{lb}$ as condensed liquid at $85^{\circ} \mathrm{C}^{19}$ ), thus, the steam supplied $6,850,000 \mathrm{btu} / \mathrm{hr}$ $(1.73 \mathrm{E}+9 \mathrm{cal} / \mathrm{hr})$ and $1,140,000 \mathrm{btu} / \mathrm{hr}(2.88 \mathrm{E}+8 \mathrm{cal} / \mathrm{hr})$ at $6000 \mathrm{lb} / \mathrm{hr}$ and $1000 \mathrm{lb} / \mathrm{hr}$ respectively. Since the tank heat loss rate is estimated at $8 \mathrm{E}+7 \mathrm{cal} / \mathrm{hr}$ and assuming a similar waste heat generation rate to Tank $51 \mathrm{LTAD}$ of about $2.3 \mathrm{E}+7 \mathrm{cal} / \mathrm{hr}$, a $1000 \mathrm{lb} / \mathrm{hr}$ steam supply would have supplied an excess of $2.3 \mathrm{E}+8 \mathrm{cal} / \mathrm{hr}$. A $6000 \mathrm{lb} / \mathrm{hr}$ steam supply would have supplied an excess of $1.67 \mathrm{E}+9 \mathrm{cal} / \mathrm{hr}$.

At the start of dissolution, the tank had 320,000 lbs of insoluble solids and at the end of the dissolution, the tank had 186 inches of waste slurry. ${ }^{20}$ The heat capacity, supernate density, and solids density were assumed to be the same as the slurry from LTAD as shown in Table 11 for this approximation. About $2.5 \mathrm{E}+9 \mathrm{cal}$ are needed to raise the temperature of the sludge slurry in Tank 51 one degree during LTAD. The $6000 \mathrm{lb} / \mathrm{hr}$ would increase the tank temperature at a rate of $0.67^{\circ} \mathrm{C} / \mathrm{hr}$. The 1982 demonstration reported a maximum rate of temperature increase of $0.5^{\circ} \mathrm{C} / \mathrm{hr}$ in Tank 42 , a tank of similar design to Tank $51 .^{2}$ During this dissolution, the slurry pumps leaked 190,000 gallons of bearing water during dissolution, which added to the thermal mass during heating and temperature maintenance. The difference may readily be attributable to the bearing water leak rate, however, there is no information about the status of the annulus ventilation system. An operating annulus ventilation system would increase the rate of heat loss. Also, note that the aluminum dissolution reaction is endothermic and the energy consumption rate is assumed to be a small relative the total energy inflow. The rate of energy consumption may become significant as the tank temperature approaches $85^{\circ} \mathrm{C}$.

Tank 51 used from 2 to 4 slurry pumps driven by 150 horsepower motors. The maximum energy that a 150 horsepower motor can supply is approximately $9.62 \mathrm{E}+7 \mathrm{cal} / \mathrm{hr}$. Assuming all the energy translates to energy input to the liquid, one slurry pump effectively provides enough energy to maintain temperature above $45^{\circ} \mathrm{C}$. Two or more slurry pumps will produce a sensible temperature increase. Each additional slurry pump results in a predicted temperature increase of about $0.04^{\circ} \mathrm{C} / \mathrm{hr}$ or $0.9^{\circ} \mathrm{C} /$ day, which is similar to what was observed during LTAD. During LTAD, one or two of four pumps were not functional at various times for a variety of maintenance reasons, so data from long periods of steady operation are not generally available. One period from 12/24/07 to $12 / 29 / 07$ using 3 slurry pumps steadily increased the sludge temperature from $55^{\circ} \mathrm{C}$ to $63^{\circ} \mathrm{C}$ or $1.4^{\circ} \mathrm{C} /$ day. The estimated heat input would predict a maximum of $1.8^{\circ} \mathrm{C} /$ day. The pumps likely deliver somewhat less energy to the tank than the motor rating, depending on rotation rate and fluid properties. Electricity consumption of the motor would likely indicate actual energy rate delivered to the pump, but that data was not available for this evaluation. One 
would also expect that the rate of temperature change would decrease due to the increasing rate of heat loss as the tank temperature increased.

\subsection{Heat Loss Summary}

The rate of heat loss from Tank 51 appears unexpectedly linear with respect to tank temperature and time. This result may be due to the relatively limited range of temperature loss experienced during the quiescent periods, but still provides an approximation for estimating temperature changes for future aluminum dissolution processes. With no heat generation in a waste tank, the rate of heat loss is estimated at $8 \mathrm{E}+7$ $\mathrm{cal} / \mathrm{hr}$. Assuming slurry heat capacities are the same as estimated for LTAD sludge slurry, the temperature loss rate would be about $0.8^{\circ} \mathrm{C} /$ day. The actual rate of temperature change would be adjusted for the rate of heat generation. Sludge slurry from LTAD was estimated to generate about $2.3 \mathrm{E}+7 \mathrm{cal} / \mathrm{hr}$, effectively reducing the rate of temperature decay to $0.6^{\circ} \mathrm{C} /$ day. The heat loss rate can be used to predict the rate of temperature gain for a given energy input.

\section{COMPARISON OF LTAD DISSOLUTION RATE TO DISSOLUTION RATE MODEL}

\subsection{Dissolution Rate Model}

Equation (1) shows a kinetic model developed for dissolving aluminum from SRS sludge that is based on dissolution test data, in tank demonstration data, and literature data. ${ }^{21}$ The rate model is based on dissolving boehmite, which is believed to be the slowest dissolving form of aluminum in the waste.

$$
\mathrm{t}=\frac{\alpha \mathrm{F}(w f, \alpha)}{\left(\eta^{0} \gamma_{ \pm}^{1 / 2} \mathrm{~A}\right) \sqrt{\mathrm{C}_{\mathrm{OH}}^{0}}} \mathrm{e}^{\frac{14800}{\mathrm{~T}}}
$$

where

$$
\begin{aligned}
\mathrm{t}= & \text { Dissolution time, } \mathrm{hr} \\
\mathrm{F}(\mathrm{wf}, \alpha)= & \frac{1}{\sqrt{\alpha(\alpha-1)}} \mathrm{Ln}\left|\frac{(\sqrt{\alpha}-\sqrt{\alpha-1})(\sqrt{\alpha-1+\mathrm{wf}}+\sqrt{\alpha-1}) \mid}{(\sqrt{\alpha}+\sqrt{\alpha-1})(\sqrt{\alpha-1+\mathrm{wf}}-\sqrt{\alpha-1})}\right| \\
\alpha= & \text { Mole ratio at initial conditions of free } \mathrm{OH} \text { ion in the liquid phase relative to } \mathrm{Al} \text { in the solid phase, dimensionless } \\
\mathrm{C}_{\mathrm{OH}}^{0}= & \text { Initial liquid phase concentration of free } \mathrm{OH} \text { ion in molal units, gmol/kg water } \\
\mathrm{T}= & \text { Dissolution operating temperature, } \mathrm{K} \\
\mathrm{wf}= & \text { Weight fraction of initial Al remaining in solids at the conclusion of the dissolution process, dimensionless } \\
\eta^{0}= & \text { the initial specific surface area of aluminum hydroxide solids, } \mathrm{m}^{2} / \mathrm{gmol} \text { Al } \\
\gamma_{ \pm}= & \text {Constant defined in the batch dissolution model development equivalent to variation of }{ }_{25} \mathrm{a}_{\mathrm{NaOH}}, \\
& \quad \text { activity of NaOH in water at } 25^{\circ} \mathrm{C}, \text { with free } \mathrm{OH} \text { molality for the liquid phase where }{ }_{25} \mathrm{a}_{\mathrm{NaOH}} \sim \\
& \gamma_{ \pm} \mathrm{C}_{\mathrm{OH}}, \text { dimensionless. } \\
\mathrm{A}= & \text { Boehmite dissolution reaction pre-exponential rate constant, mol Al- } \mathrm{m}^{-2}-\mathrm{hr}^{-1} \text { - }(\mathrm{mol} \mathrm{OH} / \mathrm{kg} \mathrm{water})^{1 / 2}
\end{aligned}
$$


The rate equation used by the transient material balance is based on a number of simplifying assumptions, including:

- Sufficient solids and liquid mixing is provided,

- Aluminum hydroxide solids are primarily present in the form of boehmite,

- The dissolution endpoint composition is selected such that the solubility limit does not influence the dissolution rate at the dissolution operating temperature,

- The change in liquid phase water mass is negligible over the dissolution time period,

- The operating temperature is constant over the dissolution time period, and

- The liquid phase sodium hydroxide activity is approximately proportional to the molal concentration of free hydroxide ion in solution.

The rate equation is applicable for hydroxide ion concentrations less than $6.8 \mathrm{M}$. A shift in reaction order occurs above this concentration and the rate equation would be expected to over-estimate times to dissolve aluminum while the liquid phase is at free hydroxide ion concentration greater than $6.8 \mathrm{M}$.

The group of constants, $\left(\eta^{0} \gamma_{ \pm}^{1 / 2} A\right)$, was fitted to simulated and real waste dissolution data as shown in Table 12. One might note that the cold chemical boehmite tended to produce larger constants than real waste or complex simulated sludge. To best represent SRS waste, the recommended constant to apply was $2 \mathrm{E} 15$. One might note that the group of constants contains the initial specific surface area of aluminum hydroxide. Little or no data is available to determine the specific surface area. However, the value is a constant for any given dissolution and may vary some from batch to batch. The variance in the test data is likely due to the variance in initial specific surface area.

Table 12: Summary of Aluminum Dissolution Rate Equation Constants Estimated from Test Data

\begin{tabular}{|l|l|c|}
\hline \multicolumn{2}{|c|}{ Estimate Basis } & \multirow{2}{*}{$\begin{array}{c}\text { Estimated Value of }\left(\eta^{0} \gamma_{ \pm}^{1 / 2} \mathrm{~A}\right), \\
\mathrm{hr}^{-1}-(\mathrm{gmol} \mathrm{OH} / \mathrm{kg} \mathrm{water})^{-1 / 2}\end{array}$} \\
\hline Test Scale & Solid Material Source & $4.8 \times 10^{15}$ \\
\cline { 2 - 3 } $\begin{array}{l}\text { Laboratory Scale } \\
\text { Tests }\end{array}$ & Cold Chemical Boehmite & $4.6 \times 10^{15}$ \\
\cline { 2 - 3 } & Cold Chemical Boehmite + Sand & $8.0 \times 10^{15}$ \\
\cline { 2 - 3 } & Cold Chemical Boehmite & $1.6 \times 10^{15}$ \\
\cline { 2 - 3 } & $\begin{array}{l}\text { Estimated Boehmite Fraction of Actual Tank 12 } \\
\text { Sludge (Archived Sample) }\end{array}$ & $2.4 \times 10^{15}$ \\
\hline Pilot Scale Test & Boehmite Fraction of Synthetic Tank 11 Sludge & $2.8 \times 10^{15}$ \\
\hline $\begin{array}{l}\text { Full Scale } \\
\text { Demonstration }\end{array}$ & $\begin{array}{l}\text { Estimated Boehmite Fraction of Actual Tank 15 } \\
\text { Sludge }\end{array}$ & \\
\hline
\end{tabular}

\subsection{Model Versus Field Observation}

The dissolution rate observed during LTAD was higher than estimated with the recommended value for the constant as illustrated in Figure 7. The dissolution temperature ranged from 55 to $63^{\circ} \mathrm{C}$ and was within a couple of degrees of $60^{\circ} \mathrm{C}$ for most of the time, thus, the dissolution was compared to the model at $60^{\circ} \mathrm{C}$. Laboratory test of the LTAD sludge indicate that about $97 \%$ of the aluminum was in the form of boehmite, ${ }^{22}$ thus, the initial rapid dissolution of any gibbsite is not practically observed and no adjustment is needed to account for gibbsite or a rapid dissolving form of aluminum. A best fit of the LTAD data results in $\left(\eta^{0} \gamma_{ \pm}^{1 / 2} \mathrm{~A}\right)=7 \mathrm{E} 15$. This value is in the range measured in the previous test data, but is roughly 3 times higher than previous actual waste results. 
The higher value for the constant suggests that the specific surface area of the LTAD sludge was about 3 times larger. The sludge for LTAD consisted of a portion of the Tank 11 sludge slurry prepared for Sludge Batch 4. This sludge slurry settled unusually slowly compared to the three prior sludge batches. The average particle size of the sludge for LTAD was similar to the average particle size measured from a Sludge Batch 3 sample. However, the measured particle size range was much larger for Sludge Batch 3 than for sludge used in LTAD, which is the result of a larger portion of less than 10.6 micron particles in Sludge Batch $4 .^{23}$ The particle size data implies a larger specific surface area due to the propensity of a larger fraction of smaller particles, but it is not clear that the difference would be as large as 3 times. In fact, the mean particle size by number of particles for Sludge Batch 3 sludge was 1.4 versus 1.8 microns for the sludge used in LTAD, which suggests a smaller specific surface area. Particle porosity and other factors that were not measured also affect the specific surface area. Particle size data from the sludge slurry used in the 1982 aluminum dissolution demonstration was not available for comparison.

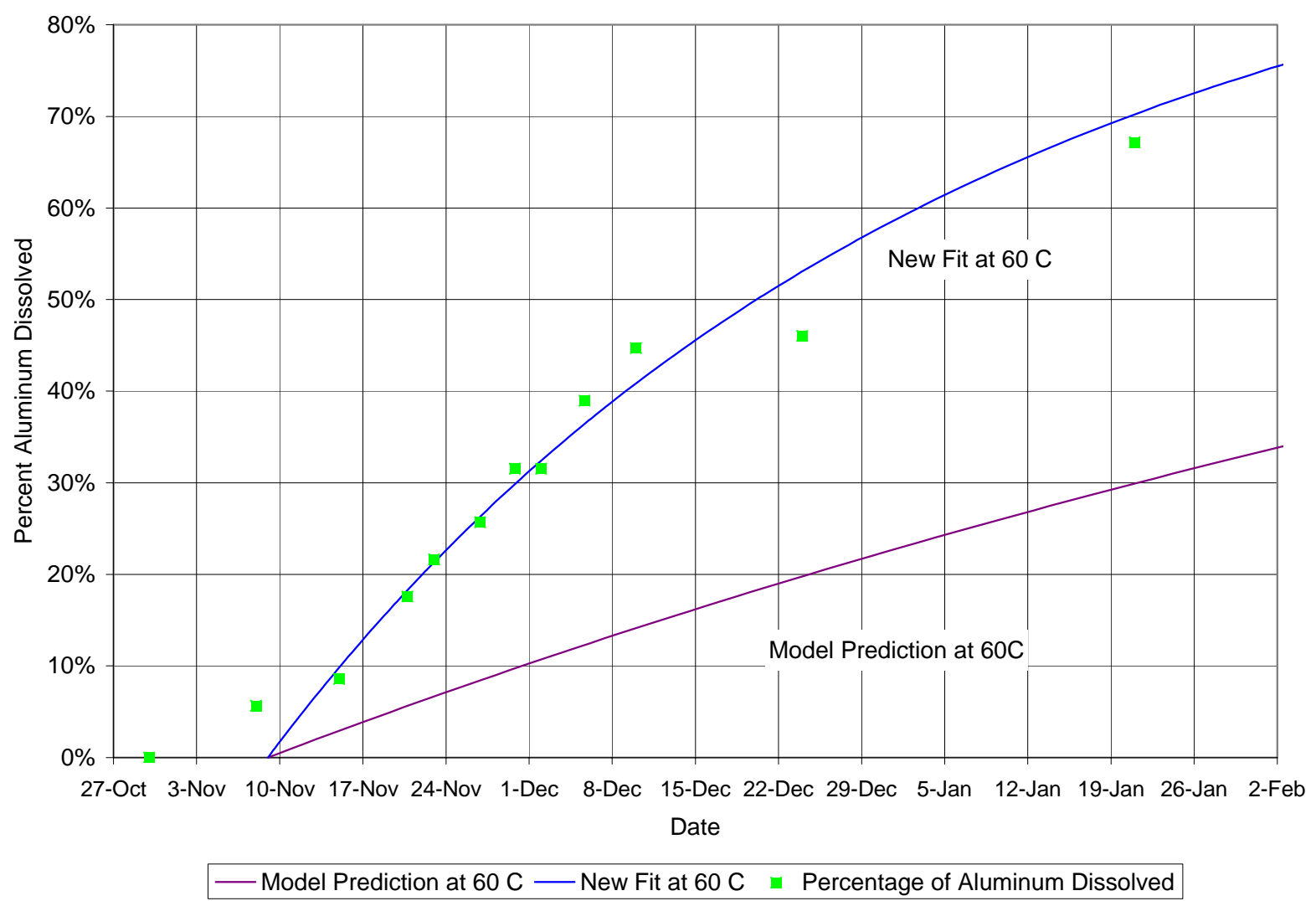

Figure 7: LTAD Dissolution Rate Data Versus the Dissolution Rate Model 


\subsection{Future Application of the Model}

Planning for future aluminum dissolution should continue to use the original value for $\left(\eta^{0} \gamma_{ \pm}^{1 / 2} A\right)$ until more information is available to determine a better value. One possible source of new information for reaction rate data consists of laboratory-scale dissolution tests conducted before any full-scale dissolution. These tests will likely provide data to refine the rate constant for the specific batch.

Laboratory-scale test data was obtained for LTAD. However, laboratory-scale testing on a sample of the same sludge used for LTAD produced a significantly faster dissolution result than experienced during LTAD. The dissolution rate during the laboratory demonstration of LTAD at $55^{\circ} \mathrm{C}$ started faster than would be expected by the model, but slowed after the first 10 days or so to match the shape of the rate curve from the model. Figure 8 illustrates the laboratory demonstration of LTAD versus the rate model fit to the laboratory data. At $55^{\circ} \mathrm{C}$ the value for the constant $\left(\eta^{0} \gamma_{ \pm}^{1 / 2} \mathrm{~A}\right)$ fitted to the laboratory test data as shown in Figure 8 is 14E15, which is much higher than observed at full-scale. Notice that the rate of dissolution at full-scale has a close match to the model, but the laboratory test shows a much more rapid dissolution rate in the first 10 days than at full-scale. Furthermore, the observed laboratory dissolution rate closely matches the full-scale observed rates after 10 days in the laboratory and 20 days in the field, as if there were a 10 day induction period at full-scale. However, the dissolution temperature in Tank 51 was 4 to 8 degrees warmer for nearly the entire dissolution period after all caustic additions were complete.

One of the differences between lab-scale and full-scale is that the caustic addition and tank heat up period of the full-scale took much longer. The first 7 days or so of the modeled full-scale dissolution occurs before all caustic is added or the tank is at full temperature. However, even after both were at target temperatures, the lab-scale test dissolved aluminum faster than would be predicted from the full-scale results. Effectively, the lab-scale test was faster or matched the full-scale dissolution rate even though it was maintained at a lower temperature.

Another difference is that the laboratory test was conducted using a blade mixer versus standard slurry pumps in Tank 51. The blade mixer likely introduced a larger volume exposed to a high shear rate relative to the total volume than was experienced in the waste tank. Practically, sludge particles would have cycled through the high shear region more frequently than in the waste tank. As such, the laboratory test may have effectively increased specific surface area by shearing the particle size down. No measurements were made to determine if this effect occurred, but should be considered in any future laboratory tests. 
SRNS-STI-2008-00021

REVISION 0

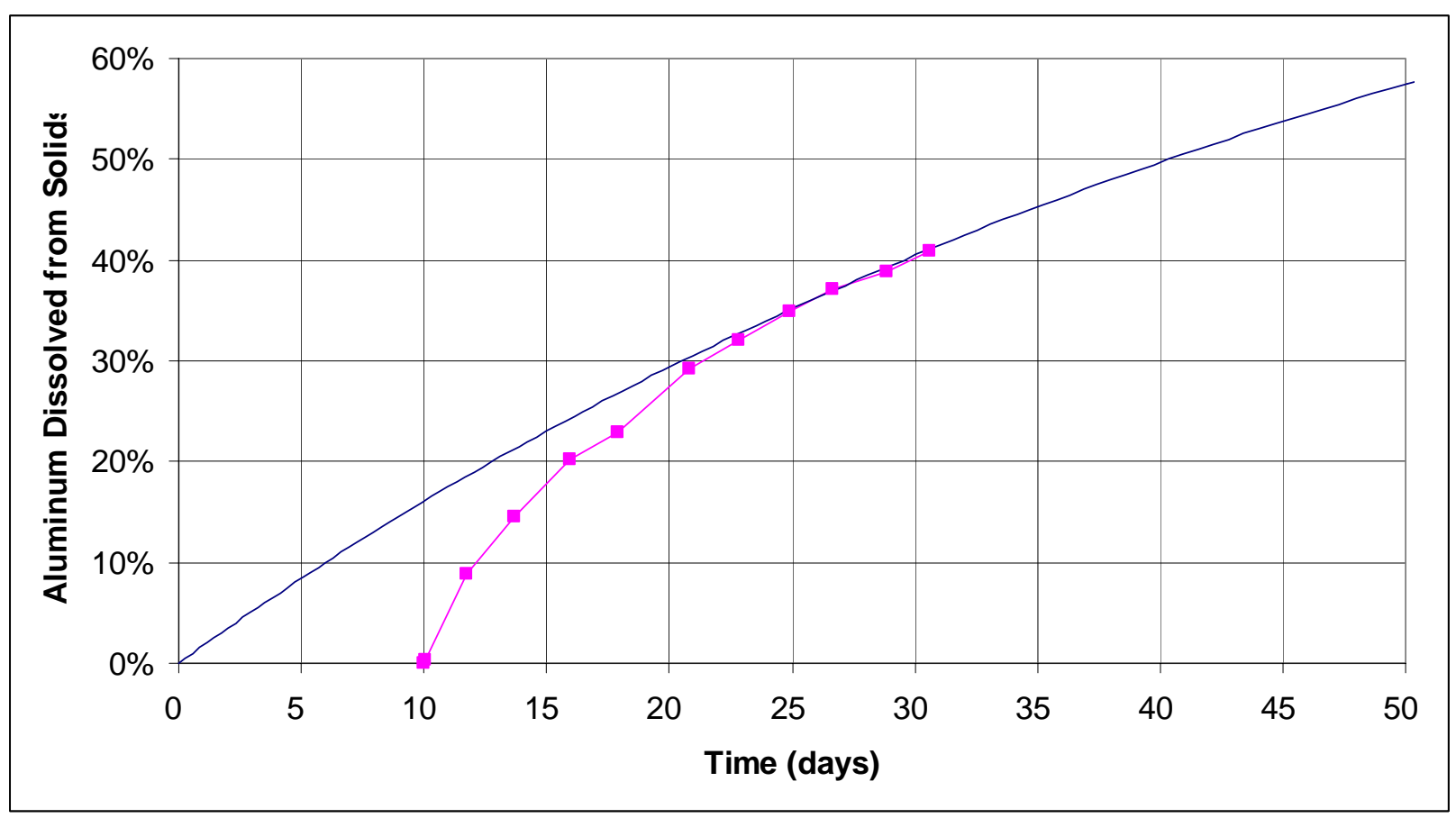

Figure 8: Lab Demonstration of LTAD Dissolution Rate Data Versus the Dissolution Rate Model

\subsection{Rate Model Summary}

LTAD dissolution rate was about 3 times higher than originally expected and was likely due to a higher specific area of the aluminum sludge particles. The rate model accurately predicts the rate of change in the dissolution rate after calibration to the specific surface area characteristics. The current parametric fit for the rate equation should continue to be used for planning purposes as this will likely produce a reasonable estimate for time needed to reach the desired extent of reaction.

Laboratory-scale dissolution rate tests do not accurately reflect the field observations. Any future laboratory-scale tests will likely exhibit a faster initial dissolution rate for up to the first 10 days of laboratory dissolution. Afterwards, the dissolution will likely tend to approach field observation rates. Some or all of the differences may be attributable to shearing of the particles, thus, decreasing the specific area and increase the dissolution rate. In future tests, care should be should taken to minimize particle shearing, which will avoid over predicting in-tank dissolution rates.

\section{CONCLUSIONS}

LTAD was successfully completed in Tank 51 with minimal waste tank changes. The following general conclusions may be drawn about the LTAD process:

- Dissolution at about $60^{\circ} \mathrm{C}$ for 46 days dissolved $64 \%$ of the aluminum from the sludge slurry.

- The aluminum-laden leach solution decanted to Tank 11 can be blended with a wide variety of supernates without risk of precipitating the dissolved aluminum based on thermodynamic chemical equilibrium models. 
- Uranium and plutonium leached into solution without corresponding leaching of iron or metal other than aluminum, but the total mass leached was a small fraction of the total uranium and plutonium in the sludge.

- The concentration of uranium and plutonium in the leach solution was indistinguishable from other tank farm supernates, thus, the leach solutions can be managed relative to the risk of criticality like any other supernate.

- A small amount of mercury leached into solution from the sludge causing the liquid phase concentration to increase 6 to 10 fold, which is consistent with the 4 to 14 fold increase observed during the 1982 aluminum dissolution demonstration.

- Chromium did not dissolve during LTAD.

- Chloride concentration increased in the liquid phase during LTAD due to chloride contamination in the $50 \%$ sodium hydroxide solution.

- The rate of heat loss from Tank 51 at temperatures above $45^{\circ} \mathrm{C}$ appeared linear and predictable at $8 \mathrm{E}+7 \mathrm{cal} / \mathrm{hr}$.

- The rate of heat transfer from Tank 51 did not follow a simplified bulk heat transfer model.

- Prediction of the aluminum dissolution rate was prone to error due to a lack active specific surface area data of sludge particles.

- The higher than expected dissolution rate during LTAD was likely due to smaller than expected particle sizes of most of the sludge particles.

While evaluating the LTAD process, the dissolved salt solution from Tank 41 that was stored and sampled in Tank 49 was determined to be supersaturated relative to aluminum. Supersaturation in Tank 49 is not a risk to LTAD. However, storing and processing of this supernate carries a risk of solids precipitation, primarily in the form of gibbsite or boehmite. Blending with the supernate in Tank 11 neither increases nor decreases this risk.

LTAD was initiated as an opportunity to substantially mitigate the planned increase in canister production and DWPF lifecycle after the realization of more sludge solids stored in the HLW tanks. As determined from the preliminary evaluation of LTAD, the direct benefit of the decanted liquid stored in Tank 11 represents 45 canisters with potential indirect benefits for much larger reductions. Application of an aluminum dissolution process to the remaining high aluminum content sludge will potentially reduce the planned canister production by several hundred canisters. The successful completion of LTAD shows that:

- Aluminum dissolution can be accomplished without significant modification to the existing facilities.

- Boehmite, a form of aluminum once considered relatively difficult to dissolve from HLW, dissolved readily by the LTAD process.

- Dissolution can be accomplished given an adequate dissolution period even though dissolution is slow.

Recommendations:

- Continue application of the aluminum dissolution process on high aluminum content sludge.

- Planning for any specific blend of Tank 11 supernate should be evaluated for the risk of precipitating aluminum. 
- Include chloride concentration in process planning and monitoring of future aluminum dissolution processes to avoid the risk of chloride-induced corrosion in stainless steel or undesirable effects on downstream processes.

- Use the existing rate model for planning aluminum dissolution until batch specific data is available to refine the predicted dissolution rate.

\section{REFERENCES}

1 B. A. Hamm and H. H. Elder, "Savannah River Site Sludge Characterization Model Using Dial-Up Factors”, CBU-PIT-2006-00058, Rev. 0, March 2006, p. 8.

2 T. Motyka, “Technical Data Summary for In-Tank Sludge Processing”, DPSTD-84-100, April 1984.

3 J. A. Pike and J. M. Gillam, "Flowsheet for Aluminum Removal from Sludge Batch 5", LWO-PIT2007-00042, Rev. 2, September 26, 2007.

4 J. A. Pike, "Estimated Caustic Addition to Tank 11 for Low Temperature Aluminum Dissolution", LWO-LWE-2008-00015, Rev. 0, January 24, 2008.

5 D. L. McWhorter, "Task Requirements and Criteria Modular Caustic Side Solvent Extraction Unit (MCU)”, G-TC-H-00041, Rev. 12, January 8, 2008, page 41.

6 R. A. Dimenna, et. al., "Bases, Assumptions, and Results of the Flowsheet Calculations for the Decision Phase Salt Disposition Alternatives”, WSRC-RP-99-00006, Rev. 3, May 2001.

7 J. A. Pike, "Preliminary Results for Low Temperature Aluminum Removal from Sludge Batch 5", LWO-LWE-2008-00067, Rev. 0, March 24, 2008.

8 C. J. Martino, "Analysis of Tank 49H Samples (HTF-064 - 066) for Saltstone Waste Acceptance Criteria Constituents”, WSRC-TR-2005-00336, Rev. 0, August 11, 2005.

9 R. E. Eibling and B. A. Hamm, "Demonstration of In-Tank Sludge Processing Part III. Effect of Processing on Minor Waste Components”, DPST-84-795, October 1, 1984.

10 M. S. Hay and D. J. McCabe, "Preliminary Characterization Data for the Tank 51H and Tank 11H Post Aluminum Dissolution Process Samples”, SRNL-CST-2008-00015, May 17, 2008.

11 M. S. Hay and D. J. McCabe, "Characterization of Tank 11H and Tank 51H Post Aluminum Dissolution Process Samples”, WSRC-STI-2008-00227, Rev. 0, May 2008.

12 J. A. Pike and N. A. Johns, "In Process Sample Results for Low-Temperature Aluminum Dissolution”, LWO-LWE-2008-00050, Rev. 0, March 10, 2008.

13 M. S. Hay, et. al., "Characterization and Aluminum Dissolution Demonstration with a 3Liter Tank 51H Sample”, WSRC-STI-2007-00697, Rev. 0, February 2008. 
14 S. H. Reboul, "Fate of Uranium, Plutonium, and Other Waste Constituents During Aluminum Dissolution", LWO-PIT-2007-00060, Rev. 0, June 29, 2007.

15 Hamm, B. A., R. E. Eibling, and John Fowler, "Demonstration of In-tank Sludge Processing. Part I: Aluminum Dissolution, Sludge Washing and Settling Results," DPST-83-668, July 12, 1983.

16 Eibling, R. E. and B. A. Hamm, "Demonstration of In-tank Sludge Processing. Part II: Effect of Processing on Radionuclides," DPST-83-932, October 19, 1983.

17 Lumetta, G. J., K. J. Carson, L. P. Darnell, L. R. Greenwood, F. V. Hoopes, R. L. Sell, S. I. Sinkov, C. Z. Soderquist, M. W. Urie, and J. J. Wagner, "Caustic Leaching of Hanford Tank S-110 Sludge," PNNL-13702, October 2001.

18 J. M. Gillam, "Projected Sludge Settling Results for Sludge Batch 5”, X-ESR-H-00130, Rev. 0, March 26, 2008.

19 Perry's Chemical Engineering Handbook, Seventh Edition, McGraw Hill, 1997, p 2 - 305.

20 R. A. Ator, "In-Tank Sludge Processing Demonstration Technical Summary", DPSP 83-17-14, September 13, 1984.

21 A. L. Pajunen, "Evaluation of Boehmite Dissolution Kinetics in Tank Waste" LWO-PIT-2006-00006, Rev. 0, September 28, 2006.

22 M. S. Hay, K. Adu-Wusu, and D. J. McCabe, "Determination of the Fraction of Gibbsite and Boehmite Forms of Aluminum in the Tank 51H Sludge", WSRC-STI-2008-00366, Rev. 0, August 2008.

23 D. R. Click, "Tank 51H-Sludge Batch 4 Particle Size Evaluation and Comparison to 40 Sludge Batch 3", SRNL-ADS-2005-00646, November 10, 2005 